\title{
Revisão, análise cladística e biogeografia de Coccoderus Buquet (Coleoptera, Cerambycidae)
}

\author{
Marcela L. Monné ${ }^{1,2}$ \\ ${ }^{1}$ Museu de Zoologia, Universidade de São Paulo. Caixa Postal 42494, 04218-970 São Paulo-SP, Brasil. \\ ${ }^{2}$ Bolsista da FAPESP.
}

\begin{abstract}
Revision, cladistic analysis and biogeography of Coccoderus Buquet (Coleoptera, Cerambycidae). A revision of the South American genus Coccoderus is presented. Ten species are recognized, of which C. sexguttatus, previously considered a synonym of $C$. amazonicus, is reinstated. Key to identification and illustrations of the species are added. The cladistic analysis, based on 31 morphological characters and 12 taxa, resulted in two equally most parsimonious cladograms and in both the monophyly of Coccoderus is supported by five synapomorphies. Notes on biogeography and maps of distribution are provided. Seven species occurs in sympatry on Cerrado, of which two species also occur in the Amazon Forest and two on the Atlantic Forest. Two species occurs only in the Amazon Forest and one species in the oriental forests of the Andes.
\end{abstract}

KEYWORDS. Biogeography; Cerambycinae; cladistic analysis; South America; Torneutini.

RESUMO. Revisão, análise cladística e biogeografia de Coccoderus Buquet (Coleoptera, Cerambycidae). A revisão do gênero sul-americano Coccoderus é apresentada. Dez espécies são reconhecidas, das quais C. sexguttatus, considerada sinônimo de C. amazonicus, é revalidada. São fornecidas chave de identificação e ilustrações das espécies. A análise cladística, com 31 caracteres morfológicos e 12 táxons, resultou em dois cladogramas igualmente mais parcimoniosos e em ambos a monofilia de Coccoderus é suportada por cinco sinapomorfias. São incluídos notas sobre biogeografia e mapas de distribuição. Sete espécies ocorrem em simpatria no Cerrado, das quais duas espécies também ocorrem na Floresta Amazônica e duas na Mata Atlântica. Duas espécies ocorrem apenas na Floresta Amazônica e uma espécie nas matas orientais das encostas dos Andes.

PALAVRAS-CHAVE. América do Sul; análise cladística; Biogeografia; Cerambycinae; Torneutini.

O gênero Coccoderus Buquet, 1840 apresenta nove espécies restritas à América do Sul, ocorrendo desde a Venezuela à Argentina (Monné 1994; Tavakilian \& Monné 2002). As formas imaturas, informações sobre plantas hospedeiras e biologia estão registradas apenas para Coccoderus novempunctatus (Germar, 1824) (Bondar 1915; Silva \& Almeida 1941; Di Iorio 1998; Monné 2001).

Coccoderus foi alocado por Fragoso et al. (1987) na tribo Torneutini Thomson, 1860, subtribo Bothriospilina Lane, 1950. Monné \& Napp (in press), na análise cladística entre os gêneros de Torneutini, consideraram a tribo parafilética e Bothriospilina foi elevada ao nível de tribo. Coccoderus está situado atualmente, junto com 14 gêneros, na tribo Torneutini por apresentarem as seguintes sinapomorfias: antenas com 12 antenômeros; proendosternito com duas projeções; processo mesosternal mais estreito que a cavidade mesocoxal e com projeções laterais; ápice dos élitros com espinho sutural; empódio reduzido, a porção projetada entre as unhas ausente (Monné \& Napp in press).

Neste trabalho, o gênero e suas espécies são revistos; propõe-se a revalidação de $C$. sexguttatus Waterhouse, 1880; apresenta-se chave para identificação das espécies e ilustrações; por meio da análise cladística propõem-se hipóteses de relações de parentesco entre as espécies de Coccoderus e são fornecidos comentários sobre a biogeografia, incluindo mapas de distribuição.

\section{REVISÃO DA LITERATURA}

O gênero Coccoderus foi proposto por Buquet (1840) que o considerou próximo de Chlorida Audinet-Serville, 1834 e Phaenicocerus [=Diploschema] e descreveu C. bisignatus, C. sexmaculatus e C. tuberculatus.

Blanchard (1847) descreveu C. tristis da Bolívia.

White (1853) propôs a sinonímia entre C. tuberculatus Buquet, 1840 e C. novempunctatus (Germar, 1824).

Thomson (1864) designou C. bisignatus Buquet, 1840 como espécie-tipo de Coccoderus.

Bates (1870) descreveu C. amazonicus do Pará, Brasil e a diferenciou de C. bisignatus e C. sexmaculatus pelos ápices dos antenômeros III-V inermes.

Waterhouse (1880) descreveu C. sexguttatus do Equador.

Gounelle (1909) descreveu C. speciosus de Goiás, Brasil e a distinguiu das demais espécies, com três pares de manchas ebúrneas nos élitros, pelos élitros densamente pontuados e ápice apenas com espinho sutural; nas demais espécies os élitros são pouco pontuados e biespinhosos no ápice.

Lane (1939) descreveu C. teixeirai do Mato Grosso, Brasil e a considerou semelhante à $C$. speciosus, diferenciando-a pelos élitros não pontuados e pelos meso- e metafêmures sem espinhos nos ápices internos.

Lane (1949) descreveu C. sicki do Mato Grosso, Brasil, e considerou-a próxima de $C$. sexmaculatus, $C$. amazonicus e 
C. sexguttatus pela presença de dois espinhos nos ápices elitrais. Redescreveu C. sexmaculatus salientando, principalmente, o dimorfismo sexual nas mandíbulas e nos lobos oculares inferiores.

Fuchs (1964) descreveu C. longespinicornis do Mato Grosso, Brasil, e a distinguiu das demais espécies pelas distintas projeções espiniformes nas antenas.

Lane \& Martins (1965) descreveram C. spinosus do Mato Grosso, Brasil e a diferenciaram das demais espécies que apresentam élitros com três pares de manchas ebúrneas e ápices biespinhosos, principalmente, pelas antenas fortemente espinhosas e ausência de tubérculos aos lados do protórax.

Martins \& Monné (1980) apresentaram chave de identificação para as espécies de Coccoderus.propuseram três sinonímias: C. sexguttatus Waterhouse, $1880=C$. amazonicus Bates, 1870; C. spinosus Lane \& Martins, $1965=C$. longespinicornis Fuchs, 1964; C. teixeirai Lane, $1939=C$. speciosus Gounelle, 1909.

Martins (1985) descreveu C. biguttatus da Bolívia e a considerou semelhante a C. bisignatus e $C$. speciosus.

Tavakilian \& Monné (2002) descreveram C. guianensis da Guiana Francesa e propuseram a sinonímia entre Coccoderus tristis Blanchard, 1847 e Pantomallus crassicorne Martins, 1997.

\section{MATERIAL E MÉTODOS}

As siglas mencionadas no texto correspondem às seguintes instituições: The Natural History Museum, Londres, Inglaterra (BMNH); Carnegie Museum of Natural History, Pittsburgh, Estados Unidos (CMNH); Embrapa Cerrados, Coleção Entomológica do Centro de Pesquisa Agropecuária dos Cerrados, Planaltina, Brasil (CPAC); Departamento de Zoologia, Universidade Federal do Paraná, Curitiba, Brasil (DZUP); Instituto Nacional de Pesquisas da Amazônia, Manaus, Brasil (INPA); Muséum National d'Histoire Naturelle, Paris, França (MNHN); Museu Nacional, Universidade Federal do Rio de Janeiro, Rio de Janeiro, Brasil (MNRJ); Museu de Zoologia, Universidade de São Paulo, São Paulo, Brasil (MZSP).

Foi realizado um estudo detalhado das estruturas do exoesqueleto, asas e terminálias masculina e feminina. Devido à escassez de material, apenas as seguintes espécies de Coccoderus foram dissecadas: C. novempunctatus, $C$. longespinicornis, C. sicki, C. speciosus e C. sexmaculatus. A terminologia e os procedimentos empregados na dissecação dos exemplares seguiram, respectivamente, Monné \& Napp (in press) e Marques \& Napp (1996). As informações sobre as formações vegetais, arroladas na distribuição geográfica das espécies, seguiram Hueck (1972) exceto para o Cerrado, na qual utilizou-se Ribeiro \& Walter (2001). Os mapas de distribuição geográfica das espécies basearam-se nos dados da descrição original e do material examinado.

Considerando a publicação de um catálogo (Monné 1994), as citações bibliográficas referentes a cada táxon limitam-se à descrição original, à citação de Monné (1994) e citações posteriores ao catálogo.
Análise cladística. Foram incluídos 12 táxons, sendo dois do grupo-externo. A seleção das espécies do grupo-externo, Psygmatocerus wagleri Perty, 1828 e Spathopygus eburoides (Blanchard, 1847), baseou-se na hipótese filogenética de Monné \& Napp (in press) para Torneutini.

Para confecção da matriz de dados foi utilizado o programa NEXUS 0.5.0 (Page 2001). As análises foram realizadas utilizando-se o PAUP versão 4.0b10 (Swofford 2001) e NONA versão 2.0 (Goloboff 1993) com interface Winclada versão beta 0.9.99m24 (Nixon 1999). As análises heurísticas seguiram o protocolo: seqüência de adições ao acaso ("random"), permuta de ramos por corte e reconexão ("tree bissection-reconnection swapping"), caracteres não ordenados, pesos iguais, 1.000 réplicas e otimização Acctran.

A polaridade dos caracteres foi estimada pelo método de comparação com grupo externo (Nixon \& Carpenter 1993). Para designar grupos monofiléticos não nominados formalmente utilizou-se o sistema proposto por Amorim (1982).

\section{RESULTADOS E DISCUSSÃO}

Abaixo segue a descrição dos 31 caracteres analisados e seus estados e índices de consistência (ic) e retenção (ir). A seqüência dos caracteres corresponde à da matriz de dados (Tabela I). A discussão dos caracteres baseou-se no cladograma da Fig. 91.

1. Lobos oculares: desenvolvidos (0); lobos superiores estreitos e inferiores pouco desenvolvidos (1) $(\mathrm{ic}=100$; $i r=100$ ).

Olhos com lobos superiores estreitos e inferiores pouco desenvolvidos e com aspecto triangular é uma sinapomorfia de Spathopygus + Coccoderus e corrobora Monné \& Napp (in press, figs. $13,15,16$ ). No clado C. sexmaculatus ${ }^{+}$, os machos apresentam o lobo ocular inferior parcialmente dividido, tratado como não comparável (vide caráter 2).

2. Lobo ocular inferior: não prolongado para a região ventral da cabeça (0); com prolongamento estreito (1) (ic=100; ir=100).

Lobo ocular inferior com prolongamento estreito para a região ventral da cabeça (Fig. 58) é sinapomorfia de $C$. sexmaculatus ${ }^{+}$.

3. Mandíbulas, região entre a base e o dente mediano: não escavada (0); escavada (1) (ic=100; ir $=100)$.

Mandíbulas não escavadas na região entre o dente mediano e a base ocorre em Psygmatocerus wagleri (Fig. 11). Mandíbulas profundamente escavadas (Figs. 12, 55, 57) é sinapomorfia de Spathopygus + Coccoderus. Nos machos de C. guianensis (Fig. 56) as mandíbulas são falciformes e não apresentam dente mediano, considerado não comparável.

4. Mandíbulas, bordo interno: com um dente (0); com dois dentes (1) ( $i c=100$; ir=100).

A presença de dois dentes no bordo interno das mandíbulas (Fig. 12) é autapomorfia de C. novempunctatus. 
Tabela I. Matriz de dados utilizados na análise cladística de Coccoderus. - = dados não comparáveis; ? = ausência de dados; a = 0 + - (polimorfismo).

\begin{tabular}{|c|c|c|c|c|c|c|c|c|c|c|c|c|c|c|c|c|c|c|c|c|c|c|c|c|c|c|c|c|c|c|c|c|}
\hline & 1 & & & & & & & & & & 11 & & & & & & & & & & & 21 & & & & & & & & & & 31 \\
\hline P. wagleri & 0 & 0 & 0 & 0 & 0 & 0 & 0 & 0 & 0 & 0 & 0 & 0 & 0 & 0 & 1 & 0 & 0 & 0 & 0 & 0 & 0 & 0 & 0 & 1 & 0 & 0 & 2 & 0 & 0 & 0 & 0 & 0 \\
\hline S. eburoides & 1 & 0 & 1 & 0 & 0 & 0 & 0 & 1 & 0 & 0 & 0 & 0 & 0 & 0 & 0 & 0 & 0 & 0 & 1 & 1 & 1 & 0 & 0 & 0 & 0 & 0 & 0 & 0 & 0 & 0 & 0 & 1 \\
\hline C. biguttatus & 1 & 0 & 1 & 0 & 0 & 0 & 0 & 1 & 0 & 1 & 1 & 1 & 0 & 1 & 1 & 0 & 0 & 1 & 1 & 1 & 0 & 1 & 1 & 1 & 0 & 0 & 1 & 0 & $?$ & $?$ & $?$ & $?$ \\
\hline C. speciosus & 1 & 0 & 1 & 0 & 0 & 0 & 0 & 1 & 0 & 1 & 1 & 1 & 0 & 1 & 1 & 0 & 0 & 1 & 1 & 1 & 3 & 1 & 1 & 1 & 0 & 0 & 1 & 0 & 1 & 1 & 0 & 2 \\
\hline C. longespinicornis & 1 & 0 & 1 & 0 & 0 & 0 & 0 & 2 & 0 & 1 & 0 & 0 & 0 & 0 & 1 & 0 & 1 & 1 & 1 & 1 & 2 & 0 & 0 & 2 & 0 & 1 & 2 & 0 & 0 & 1 & 1 & 2 \\
\hline C. sexguttatus & 1 & 0 & 1 & 0 & 0 & 0 & 0 & 0 & 0 & 1 & 1 & 0 & 0 & 1 & 2 & 0 & 1 & 1 & 1 & 1 & 4 & 0 & 0 & 2 & 1 & 0 & 2 & 2 & $?$ & $?$ & $?$ & $?$ \\
\hline C. sicki & 1 & 0 & 1 & 0 & 0 & 0 & 1 & 2 & 1 & 1 & 1 & 0 & 1 & 1 & 2 & 0 & 1 & 1 & 1 & 1 & 3 & 0 & 0 & 2 & 1 & 0 & 2 & 2 & 1 & 1 & 1 & 2 \\
\hline C. novempunctatus & 1 & 0 & 1 & 1 & 0 & 1 & 1 & 1 & 0 & 1 & 2 & 0 & 1 & 1 & 1 & 1 & 0 & 1 & 0 & 0 & 0 & 0 & 0 & 2 & 0 & 0 & 2 & 1 & 0 & 0 & 0 & 1 \\
\hline C. bisignatus & 1 & 0 & 1 & 0 & 1 & 0 & 0 & 0 & 0 & 1 & 1 & 0 & 1 & 1 & 1 & 1 & 0 & 1 & 1 & 1 & 0 & 0 & 0 & 2 & 0 & 0 & 2 & 1 & $?$ & $?$ & $?$ & $?$ \\
\hline C. sexmaculatus & $\mathrm{a}$ & 1 & 1 & 0 & 1 & 1 & 0 & 0 & 0 & 1 & 1 & 0 & 2 & 1 & 1 & 1 & 0 & 1 & 1 & 1 & 4 & 0 & 0 & 2 & 1 & 0 & 2 & 1 & 0 & 0 & 0 & 1 \\
\hline C. amazonicus & $\mathrm{a}$ & 1 & 1 & 0 & 2 & 1 & 0 & 0 & 0 & 1 & 1 & 0 & 1 & 1 & 1 & 1 & 0 & 1 & 1 & 1 & 2 & 0 & 0 & 2 & 1 & 0 & 2 & 1 & $?$ & $?$ & $?$ & $?$ \\
\hline C. guianensis & $\mathrm{a}$ & 1 & 1 & - & 2 & 0 & 0 & 0 & 0 & 1 & 1 & 0 & 1 & 1 & 1 & 1 & 0 & 1 & 1 & 1 & 2 & 0 & 0 & 2 & 1 & 0 & 2 & 1 & $?$ & $?$ & $?$ & $?$ \\
\hline
\end{tabular}

5. Palpos maxilares: Artículos cônicos e subiguais (0); artículos moderadamente cônicos, o segundo $1 / 3$ mais longo que o terceiro (1); artículos cilíndricos, o segundo $1 / 3$ mais curto que o terceiro (2) (ic=100; ir=100).

Artículos dos palpos maxilares moderadamente alongados, o segundo pouco mais longo que o terceiro e subigual ao apical (Fig. 16) é sinapomorfia do clado Coccoderus bisignatus + . Artículos cilíndrico-alongados, o segundo um terço mais curto que o terceiro e este subigual ao apical (Fig. 17) é sinapomorfia de $C$. amazonicus $+C$. guianensis.

6. Antenômero III, franja de pêlos: ausente (0); presente (1) $(\mathrm{ic}=30$; ir $=0)$.

Antenômero III com franja de pêlos longos na margem externa (Figs. 1, 3, 5) é sinapomorfia do grupo $C$. novempunctatus + e reverte em C. bisignatus e C. guianensis.

7. Antenômero III: mais longo que o IV (0); mais curto que o IV (1) $(i \mathrm{c}=50$; ir $=0)$.

Antenômero III mais curto que o IV (Figs. 1, 10) ocorre em C. sicki e C. novempunctatus.

8. Antenômero III, projeção espiniforme: ausente (0); presente, menor que a largura do antenômero (1); presente, maior que a largura do antenômero $(2)(\mathrm{ic}=50$; $\mathrm{ir}=50)$.

Antenômero III com projeção espiniforme mais curta que a largura do antenômero (Figs. 1, 6, 7) é sinapomorfia de Spathopygus+Coccoderus, com reversão no clado $C$. bisignatus $^{+}$. Antenômero III com projeção espiniforme mais longa que a largura do antenômero (Figs. 8, 10) é sinapomorfia do clado C. longespinicornis + e reverte para o estado plesiomórfico em C. sexguttatus.

9. Antenas, nas fêmeas: não ultrapassam os ápices elitrais (0); ultrapassam os ápices elitrais (1) (ic $=100$; ir=100).

Autapomorfia de C. sicki.

10. Lados do protórax, manchas pretas: ausentes (0); presentes (1) $(\mathrm{ic}=100$; ir $=100)$.

A presença de manchas pretas aos lados do protórax (Figs.
81-90) é uma sinapomorfia de Coccoderus. Essas manchas ocorrem na mesma região dos tubérculos aos lados do protórax, exceto em C. longespinicornis que não apresenta os tubérculos.

11. Lados do protórax, tubérculos: ausentes ( 0 ); dois pares (1); três pares (2) (ic=66; ir=50).

Presença de dois tubérculos rombos a cada lado do protórax (Figs. 82-87, 89, 90) é sinapomorfia de Coccoderus, com reversão em $C$. longespinicornis. Presença de três pares de tubérculos (Fig. 81) é uma autapomorfia de $C$. novempunctatus.

12. Pronoto, pontuação microesculturada: ausente (0); presente (1) $(i \mathrm{c}=100$; $i \mathrm{r}=100)$.

Pronoto com pontos microesculturados (Figs. 59-61) é sinapomorfia de C. biguttatus + C. speciosus.

13. Pronoto, margem anterior: truncada (0); arredondada (1); arredondada e ligeiramente sinuosa (2) (ic $=66$; ir $=75)$.

Pronoto com a margem anterior arredondada (Figs. 81, 82, $84,85,90)$ ocorre independentemente no clado $C$. novempunctatus + e em C. sicki. Pronoto com a margem anterior arredondada e ligeiramente sinuosa (Fig. 83) é uma autapomorfia de C. sexmaculatus.

14. Pronoto, tubérculos látero-posteriores: ausentes (0); presentes $(1)(\mathrm{ic}=50$; $\mathrm{ir}=50)$.

Pronoto com um par de tubérculos látero-posteriores (Figs. $82-87,89,90)$ foi considerado por Monné \& Napp (in press) como sinapomorfia de Coccoderus e corroborado neste estudo, com única reversão em $C$. longespinicornis.

15. Prosterno: plano (0); deprimido (1); intumescido (2) (ic=100; ir $=100$ ).

Prosterno plano é autapomorfia de Spathopygus e prosterno intumescido (Fig. 18) é sinapomorfia de $C$. sexguttatus + C. sicki.

16. Processo prosternal: sem tubérculo (0); com tubérculo (1) $(\mathrm{ic}=100 ; \mathrm{ir}=100)$. 
Processo prosternal com tubérculo (Fig. 19) é sinapomorfia do clado C. novempunctatus + .

17. Processo mesosternal: plano (0); convexo (1) (ic=100; ir $=100$ ).

Processo mesosternal convexo é sinapomorfia de $C$. longespinicornis ${ }^{+}$.

18. Élitros: pilosos (0); glabros (1) (ic=100; ir=100).

Élitros glabros, castanho-amarelados ou alaranjados e geralmente transparentes é sinapomorfia de Coccoderus.

19. Élitros, manchas ebúrneas entre os úmeros e o escutelo: ausentes (0); presentes (1) (ic $=50$; ir $=0)$.

Monné \& Napp (in press) consideraram élitros com três pares de manchas ebúrneas arredondadas como uma das sinapomorfias de Spathopygus + Coccoderus (exceto em Coccoderus novempunctatus). Neste estudo, a presença de manchas ebúrneas na base dos élitros foi considerada independente dos demais dois pares de manchas, já que as espécies de Coccoderus podem não apresentar as manchas, podem ocorrer manchas apenas na base dos élitros, ou ainda apresentarem três pares de manchas. A presença de manchas ebúrneas na base dos élitros (Figs. 82-90), entre os úmeros e o escutelo, é uma sinapomorfia de Spathopygus + Coccoderus, revertendo em C. novempunctatus.

20. Élitros, distância entre as manchas ebúrneas medianas e posteriores em relação ao comprimento da mancha mediana: manchas ausentes (0); 4 vezes o comprimento da mancha (1); 3 vezes o comprimento da mancha (2); 2 vezes o comprimento da mancha (3); cerca de metade do comprimento da mancha (4) $(\mathrm{ic}=57 ; \mathrm{ir}=25)$.

Nas espécies que apresentam três pares de manchas ebúrneas nos élitros evidenciou-se uma variação no comprimento das manchas. Em Spathopygus, estado 1, as manchas são diminutas, sendo o interstício entre as manchas médias e posteriores cerca de quatro vezes o comprimento da mancha mediana. Distância entre as manchas cerca de três vezes o comprimento da mancha (Figs. 84, 85, 88), estado 2 , ocorre em C. sexmaculatus + e paralelamente em $C$. longespinicornis. Distância entre as manchas cerca de duas vezes o comprimento da mancha (Figs. 87, 90), estado 3, ocorre nos clados C. biguttatus ++ , com reversão para o estado plesiomórfico em C. biguttatus. Manchas ebúrneas maiores que os interstícios (Figs. 83, 89), estado 4, ocorre independentemente em C. sexmaculatus e C. sexguttatus.

21. Élitros, depressão látero-basal: ausente (0); presente (1) $(\mathrm{ic}=100$; ir=100).

Depressão lateral na base dos élitros é sinapomorfia de Coccoderus biguttatus + C. speciosus.

22. Ápices dos élitros, espinho lateral: ausente (0); presente (1) $(\mathrm{ic}=100$; ir=100).

Ausência de espinho lateral nos ápices elitrais (Figs. 86, 87) é sinapomorfia de Coccoderus biguttatus + C. speciosus.
23. Ápice interno dos mesofêmures: sem espinho (0); com aba aguçada (1); com espinho (2) $(\mathrm{ic}=66$; ir $=50)$.

Ápice interno dos mesofêmures com aba aguçada (Figs. 86, 87) ocorre homoplasicamente em Psygmatocerus e $C$. biguttatus + . Ápices internos dos mesofêmures com espinho aguçado (Figs. 81-85, 88-90) é sinapomorfia de Coccoderus.

24. Metafêmures, forma: cilíndricos (0); ligeiramente fusiformes $(1)$ (ic $=50$; ir $=75)$.

Metafêmures ligeiramente fusiformes (Fig. 26) ocorre homoplasicamente nos clados $C$. sexmaculatus + e $C$. sexguttatus + C. sicki.

25. Metafêmures, franja de pêlos: ausente (0); presente (1) (ic $=100$; ir $=100$ ).

Presença de franja de pêlos na face ventral dos metafêmures é uma autapomorfia de $C$. longespinicornis.

26. Ápice interno dos metafêmures: sem espinho (0); com aba aguçada (1); com espinho (2) (ic=100; ir=100).

Metafêmures com espinho apical interno (Figs. 25, 26) ocorre em Psygmatocerus e na maioria das espécies de Coccoderus. Ápices dos metafêmures inermes é autapomorfia de Spathopygus e com aba aguçada é sinapomorfia de $C$. biguttatus ${ }^{+}$.

27. Esternito V, margem apical: ligeiramente sinuosa (0); sinuosa (1); truncada (2) (ic=100; ir=100).

Esternito $\mathrm{V}$ transverso e com a margem apical sinuosa foi considerado sinapomorfia de Trachyderoinia (Monné \& Napp in press). Nas espécies de Coccoderus evidenciou-se uma variação na margem apical, desde truncada a distintamente sinuosa. Margem apical do esternito $\mathrm{V}$ distintamente sinuosa (Fig. 28) é uma sinapomorfia do clado C. novempunctatus + . Esternito V com a margem apical truncada (Fig. 27) é sinapomorfia do clado C. sexguttatus $+C$. sicki.

28. Esternito VIII, machos, margem apical: sem lobos (0); com lobos (1) $(\mathrm{ic}=50$; ir $=0)$.

Esternito VIII transverso e com apófise distintamente curta é sinapomorfia de Trachyderoinia, como já observado por Fragoso et al. (1987) e Monné \& Napp (in press). Em Coccoderus e nos grupos externos a margem apical é apenas sinuosa, sendo que $C$. biguttatus ${ }^{+}+$apresenta dois lobos proeminentes (Figs. 31, 33), com reversão em $C$. longespinicornis.

29. Arco ventral, apófise em relação aos braços: mais curta (0); mais longa ( 1 ) (ic=100; ir=100).

Arco ventral com apófise mais longa que os braços (Figs. 36-38) é sinapomorfia do clado C. biguttatus ++ .

30. Arco ventral, ápice: reto ( 0$)$; curvo (1) $(\mathrm{ic}=50$; $\mathrm{ir}=0)$.

Arco ventral com ápice da apófise curva (Figs. 37, 38) é sinapomorfia do clado C. longespinicornis ${ }^{+}$.

31. Apófise do esternito VIII, fêmeas: estreito (0); ápice 

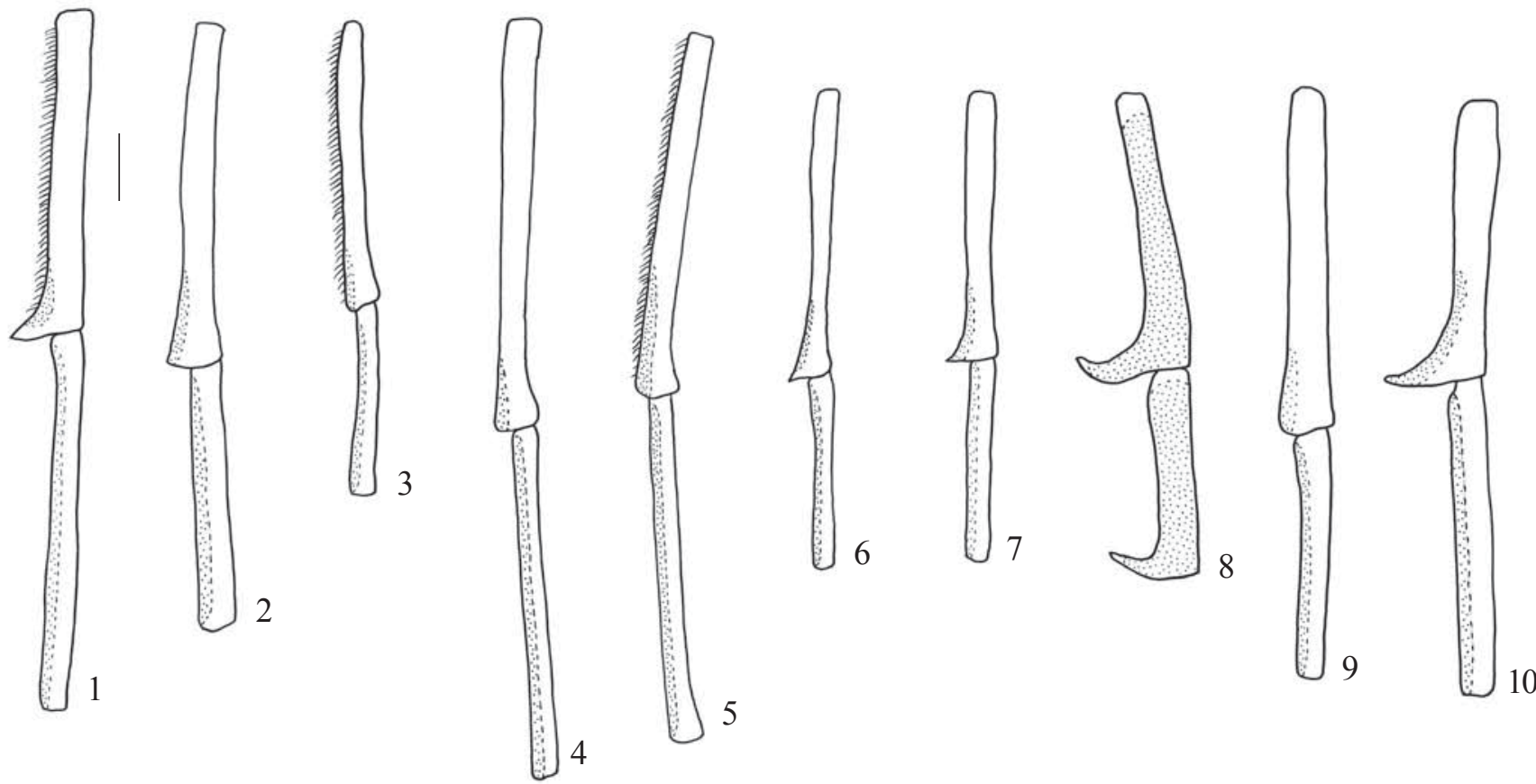

10

Figs. 1-10. Antenômeros III-IV: 1, Coccoderus novempunctatus; 2, C. bisignatus; 3, C. sexmaculatus; 4, C. guianensis; 5, C. amazonicus; 6, C. biguttatus; 7, C. speciosus; 8, C. longespinicornis; 9, C. sexguttatus; 10, C. sicki. Todas as figuras na mesma escala. Barra=1mm.

cerca de três vezes mais largo que a região mediana (1); ápice cerca de quatro vezes mais largo que a região mediana (2) (ic $=100$; ir=100).

Ápice da apófise do esternito VIII, nas fêmeas, estreito (Fig. 62) ocorre em Psygmatocerus wagleri. Ápice da apófise cerca de três vezes mais largo que a região mediana (Figs. 63, $64,69)$ é sinapomorfia de Spathopygus + Coccoderus. Ápice da apófise cerca de quatro vezes mais largo que a região mediana (Figs. 72, 75, 78) é sinapomorfia de $C$. biguttatus ++ .

A análise com 31 caracteres, 12 táxons terminais e pesos iguais resultou, tanto no NONA como no PAUP, em dois cladogramas (Figs. 91, 92) igualmente parcimoniosos com 58 passos, índice de consistência de 0,74 e índice de retenção de 0,72 (ic $=0,71$, sem autapomorfias).

A hipótese de monofilia de Coccoderus e sua relação de parentesco com Spathopygus, ambas sustentadas por cinco sinapomorfias, corroboraram os resultados obtidos por Monné \& Napp (in press). Nos dois cladogramas (Figs. 91, 92) foram obtidos, para o grupo interno, dois clados, $C$. novempunctatus + e C. biguttatus ++ . O clado C. biguttatus ++ não apresentou variação nos dois cladogramas e no clado $C$. novempunctatus + a única diferença foi o posicionamento de C. sexmaculatus, ora como grupo-irmão de $C$. guianensis $+C$. amazonicus (Fig. 91), ora como grupo-irmão de C. amazonicus (Fig. 92), consequentemente estes três táxons resultaram em politomia no consenso estrito. Optou-se pelo cladograma da Fig. 91, no qual C. guianensis é grupo-irmão de C. amazonicus, parentesco sustentado por uma sinapomorfia não homoplástica. As relações de parentesco são discutidas a seguir, na discussão do gênero e das espécies.

\section{Coccoderus Buquet, 1840}

Coccoderus Buquet, 1840: 293; Monné, 1994: 10; Monné \& Napp, in press:

Espécie-tipo. Coccoderus bisignatus Buquet, 1840, designação de Thomson, 1864: 241 .

Cabeça tão larga quanto longa. Fronte curta e oblíqua. Tubérculos anteníferos moderadamente projetados, próximos entre si e com ápices arredondados, exceto $C$. sexmaculatus com ápices aguçados. Lobos oculares superiores estreitos e inferiores com aspecto subtriangular. Mandíbulas com a região entre o dente mediano e a base profundamente escavada e com ápices aguçados (exceto machos de $C$. guianensis e $C$. sexmaculatus). Lábio (Figs. 13, 14): mento transverso; lígula semicoriácea, reduzida. Palpos labiais e maxilares com dimorfismo sexual; os maxilares mais longos que os labiais. Maxilas (Figs. 16, 17): basistipe e dististipe fusionados, gálea reduzida, sem anel esclerotinizado na base e com pêlos esparsos na região apical; lacínia reduzida e com pêlos esparsos. Antenas filiformes, ultrapassam os ápices elitrais entre os antenômeros VI-IX. Sistema porífero dividido por carena longitudinal. Escapo cilíndrico e ligeiramente expandido no ápice, com cerca da metade do comprimento do III (exceto C. sicki).

Protórax mais largo que longo, a cada lado do protórax com dois tubérculos rombos e pretos (exceto $C$. novempunctatus). Pronoto com um par de tubérculos medianos rombos e pretos e um par látero-posteriores. Cavidades coxais anteriores ligeiramente angulosas aos lados. Processo 
prosternal cerca de um terço da largura da cavidade e com articulações laterais para inserção nas procoxas. Proendosternito (Fig. 20) semicoriáceo, mais largo que longo e com duas projeções apicais. Mesosterno e metasterno com pêlos longos, densos e amarelados. Processo mesosternal (Fig. 22) cerca de $2 / 3$ da cavidade coxal e com projeções laterais para encaixe nas mesocoxas. Mesoscuto com área estridulatória. Mesendosternito (Fig. 21) dirigido para o mesepimero e fusionado à parede do mesmo; projeções para implante dos tendões reduzidas. Sutura metasternal quase alcança o processo mesosternal. Metendosternito (Fig. 23) hilecetóide, com lâminas cilíndricas, alongadas e separadas por chanfro arredondado; braços perpendiculares às lâminas; projeções para implante dos tendões, nulas; pedúnculo cerca de $1 / 3$ mais curto que as lâminas. Escutelo curto e transverso. Élitros cerca de quatro vezes o comprimento do protórax (exceto C. longespinicornis), glabros, paralelos e com ou sem manchas ebúrneas. Úmeros arredondados e não projetados. Ápices elitrais com espinho sutural e lateral, exceto $C$. speciosus e C. biguttatus, apenas com espinho sutural.

Asas (Fig. 24) com comprimento cerca de três vezes a sua maior largura; região basal da margem costal com estreita aba membranosa; lobo anal moderadamente desenvolvido; Costa (C) restrita ao terço basal; Subcosta (Sc) alcança o início da metade apical; célula da Radial fechada, pequena e de aspecto transverso, a s-m angulosa; ramo apical da Média-Anterior (MA) presente; Plical (P) desenvolvida e expandida na base em direção à Cubital; Empusal (E), na base, ligada à primeira Anal (1A); ramo a da Empusal (Ea) desenvolvida; transversa 2Aa presente e oblíqua; árculo e área carenada ausentes; Jugal (Ju) curta.

Pernas posteriores cerca de um terço mais longas que as anteriores. Procoxas e mesocoxas arredondadas. Fêmures cilíndricos ou ligeiramente fusiformes. Meso- e metafêmures com aba aguçada ou espinho apical interno. Tíbias tão longas quanto os fêmures, cilíndricas, deprimidas e ligeiramente expandidas para o ápice. Esporões tibiais robustos, paralelos e subiguais. Metatarsômero I pouco mais longo que o seguinte. Escovas tarsais compactas.

Abdome com pêlos curtos, densos e amarelados. Esternito I com comprimento subigual ao II. Esternito V (Figs. 27, 28), nos dois sexos, fortemente transverso. Tergito VIII quadrangular, com a margem apical ligeiramente sinuosa e ornada de pêlos aciculares.

Fêmea. Antenas subserreadas, alcançam o terço apical ou os ápices dos élitros. Terminália do tipo purpuriceniforme (sensu Fragoso et al. 1987). Tergito VIII (Fig. 49) transverso, com quatro lobos na margem apical e com pêlos longos e densos. Esternito VIII transverso (Figs. 64, 69, 72, 75, 78); margem apical com escova formada por pêlos aciculares, fileiras de pêlos conchoidais e pêlos espatulados alongados e encurvados; apófise esternal dilatada no ápice. Ovipositor (Figs. 50-54) curto, região distal com lobos laterais cilíndricos e curtos; estilos cilíndricos apicais; vulva membranosa e plicada longitudinalmente. Apódemas delgados e moderadamente longos.
Discussão. Embora tenham sido estudados os endosternitos, asas e terminálias, masculina e feminina, de cinco das dez espécies de Coccoderus, essas estruturas, exceto a terminália masculina, foram incluídas na descrição do gênero devido à sua uniformidade.

Coccoderus é definido pelas seguintes sinapomorfias: lados do protórax com um par de manchas pretas $\left(10_{1}\right)$; cada lado do protórax com dois tubérculos rombos $\left(11_{1}\right)$; pronoto com um par de tubérculos látero-posteriores $\left(14_{1}\right)$; élitros glabros, castanho-amarelados a alaranjados (18 $)$; e mesofêmures com espinho nos ápices internos $\left(23_{2}\right)$.

Monné \& Napp (in press) consideraram Spathopygus grupo-irmão de Coccoderus por compartilharem os seguintes caracteres: lobos oculares superiores estreitos e inferiores pouco desenvolvidos e com aspecto triangular; bordo interno das mandíbulas, com a região entre o dente e a base, profundamente escavado; élitros com três pares de manchas ebúrneas arredondadas; presença de um par de tubérculos medianos no pronoto; cavidade procoxal ligeiramente angulosa aos lados; lobo dorsal do lobo médio com ápice truncado. Desses caracteres, os dois primeiros foram corroborados como sinapomorfias neste estudo. O caráter presença de três manchas ebúrneas nos élitros, considerado uma homoplasia por Monné \& Napp (op. cit.), foi dividido neste estudo em dois caracteres, 19 e 20 , nos quais presença de manchas ebúrneas na base dos élitros (191) é uma sinapomorfia de Spathopygus + Coccoderus. Os caracteres, presença de um par de tubérculos medianos no pronoto e cavidade procoxal ligeiramente angulosa aos lados, não foram incluídos neste trabalho por já terem sido evidenciados como homoplasias. Evidenciou-se, ainda, uma variação interespecífica no ápice do lobo dorsal, não corroborando Monné \& Napp (op. cit.). Antenômero III com projeção apical espiniforme $\left(18_{1}\right)$ e esternito VIII, nas fêmeas, com ápice da apófise cerca de três vezes mais largo que a região mediana (31 $)$ são incluídos, neste estudo, como sinapomorfias de Spathopygus + Coccoderus.

Chave para as espécies de Coccoderus (modificada de Martins \& Monné 1980)

1. Élitros sem manchas ebúrneas, transparentes, com costas ebúrneas bem indicadas; a cada lado do protórax com três tubérculos pretos; habitualmente com mancha preta mediana próxima à margem anterior do pronoto (Fig. 81). Brasil (amplamente distribuída), Paraguai, Argentina, Uruguai

C. novempunctatus (Germar, 1824)

Élitros com manchas ebúrneas; a cada lado do protórax com dois tubérculos pretos; sem mancha preta mediana próxima à margem anterior do pronoto ........ 2

2(1). Élitros (Figs. 82, 86) apenas com manchas ebúrneas situadas entre os úmeros e o escutelo ....................... 3

Élitros (Figs. 83-85, 87-90) com três pares de manchas ebúrneas 

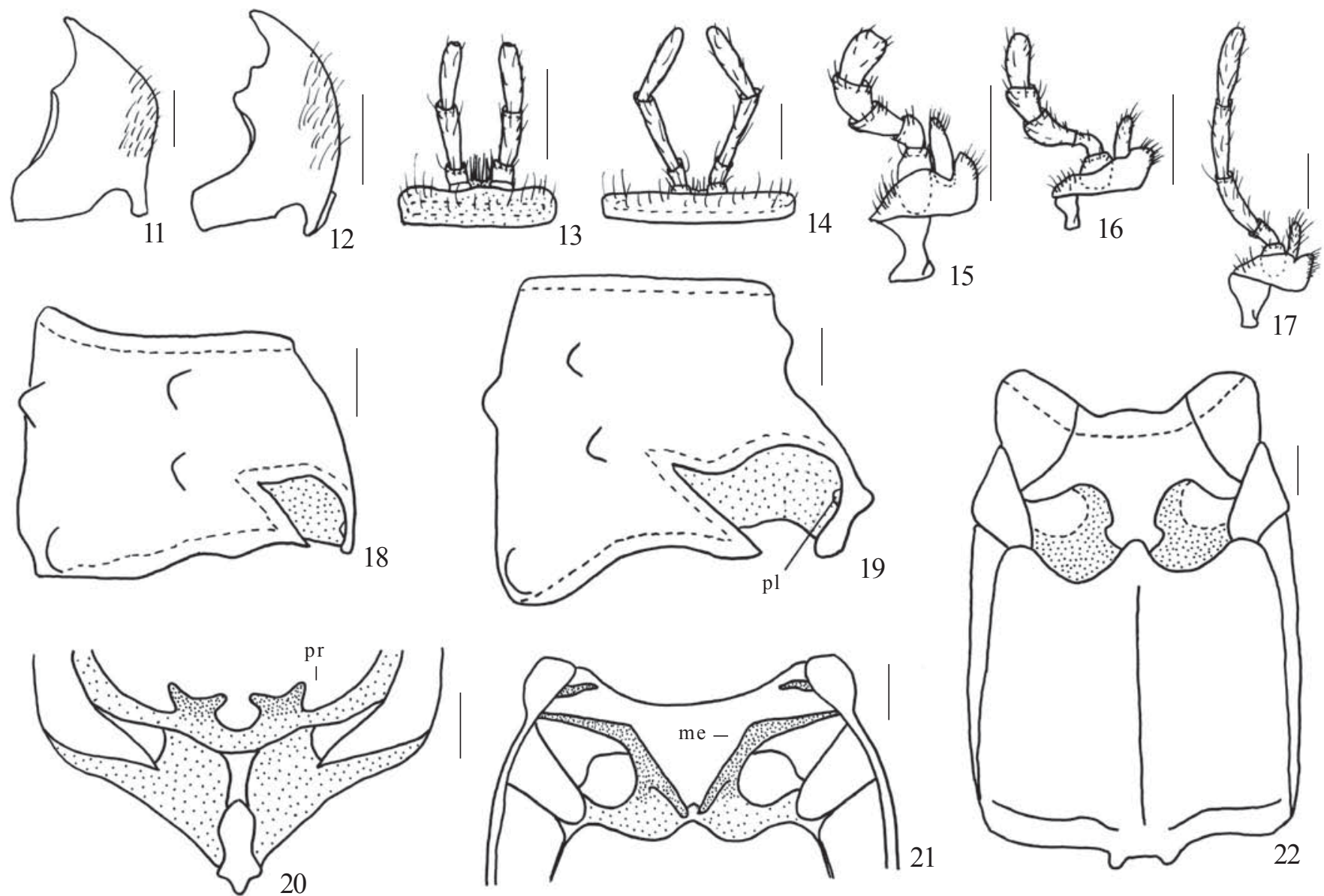

Figs. 11-22. 11, Psygmatocerus wagleri, mandíbula; Coccoderus novempunctatus, 12, mandíbula, 13, lábio; 14, C. sexmaculatus, lábio; 15, Spathopygus eburoides, maxila; 16, C. novempunctatus, maxila; 17, C. sexmaculatus, maxila; 18, C. sicki, protórax lateral; C. sexmaculatus, 19, protórax lateral, 20, proendosternito; C. novempunctatus, 21, mesendosternito, 22, mesosterno e metasterno; pl=projeção lateral; $\mathrm{pr}=$ proendosternito; $\mathrm{me}=$ metendosternito. Barra $=1 \mathrm{~mm}$.

3(2). Antenômero III com espinho apical externo (Fig. 6); processo prosternal sem tubérculo; élitros com costas ebúrneas bem indicadas (Fig. 86). Brasil (Mato Grosso), Bolívia C.biguttatus Martins, 1985

Antenômero III sem espinho apical externo (Fig. 2); processo prosternal com tubérculo; élitros com costas ebúrneas pouco evidentes (Fig. 82). Suriname, Guiana Francesa, Brasil (Amazonas)

C. bisignatus Buquet, 1840

4(2). Meso- e metafêmures (Fig. 26) com espinho longo nos ápices internos; ápices elitrais com espinho sutural e lateral

Meso- e metafêmures com abas apicais apenas projetadas; ápices elitrais apenas com espinho sutural (Fig. 87). Brasil (Bahia, Mato Grosso, Goiás, São Paulo) C. speciosus Gounelle, 1909

5(4). Antenômero III (Figs. 8, 10) com espinho desenvolvido no ápice externo

Antenômero III (Figs. 3-6) com ápice externo arredondado
6(5). Antenômeros IV-XI, nos machos, com ápice externo apenas projetado; pronoto com pontos grossos e rasos; prosterno intumescido; antenômero IV, nas fêmeas, com espinho curto e reto no ápice externo (Fig. 90). Brasil (Pará, Goiás, Rondônia, Mato Grosso) C. sicki Lane, 1949

Ápices externos dos antenômeros IV-XI, nos machos, com espinho; pronoto com pontuação profunda, alveolada e densa; prosterno deprimido transversalmente; antenômero IV, nas fêmeas, com espinho longo e curvo no ápice externo (Fig. 88). Venezuela, Peru, Brasil (Amazonas, Amapá, Pará, Piauí, Rondônia, Mato Grosso, Mato Grosso do Sul, Goiás, Minas Gerais) ......... C. longespinicornis Fuchs, 1964

7(5). Genas (Fig. 58), nos machos, com processo muito desenvolvido, projetado profundamente no lobo ocular inferior e este com prolongamento estreito para a região ventral da cabeça; prosterno (Fig. 19) deprimido transversalmente

Genas não projetadas em direção ao lobo ocular inferior e este não prolongado para a região ventral da cabeça; 
prosterno intumescido (Fig. 89). Venezuela, Colômbia, Equador, Peru . C. sexguttatus Waterhouse, 1880 reval.

8(7). Élitros com manchas ebúrneas desenvolvidas (distância entre as manchas menor que o comprimento da mancha) (Fig. 83). BRASIL (Bahia, Goiás, Minas Gerais, Espírito Santo, Rio de Janeiro, São Paulo) C. sexmaculatus Buquet, 1840

Élitros com manchas ebúrneas pequenas (distância entre as manchas cerca de três vezes o comprimento da mancha)

9(8). Mandíbulas (Fig. 56), nos machos, falciformes e sem dente no bordo interno; pronoto com pontos irregulares, rasos e densos. Antenômero III com pêlos curtos e esparsos (Fig. 85). Guiana Francesa, Brasil (Amapá) .... C. guianensis Tavakilian \& Monné, 2002

Mandíbulas (Fig. 55) não falciformes e com um dente mediano no bordo interno; pronoto com pontos finos, rasos e densos. Antenômero III com pêlos longos e densos (Fig. 84). Brasil (Pará, Minas Gerais) .......... C. amazonicus Bates, 1870

Coccoderus novempunctatus (Germar, 1824)

(Figs. 1, 12, 13, 16, 21-25, 28, 29, 34, 39, 44, 50, 64-68, 81, 91-93)

Cerambyx (Stenocorus) novempunctatus Germar, 1824: 505.

Coccoderus ? 9-punctatus; Germar in Guérin-Méneville, 1839: 330.

Coccoderus novempunctatus; White, 1853: 96 (syn.); Monné, 1994:

11; 2001: 56; Di Iorio, 1997: 162; 1998: 4, figs 1-12, 35; Di Iorio \& Zelich, 1997: 278.

Coccoderus novemmaculatus [sic]; Zajciw, 1972: 49.

Coccoderus tuberculatus Buquet, 1840: 295.

Macho. Colorido geral castanho-alaranjado a castanhoavermelhado. Élitros transparentes, amarelados exceto na base, alaranjados; sem manchas ebúrneas, com quatro costas ebúrneas bem indicadas, uma próxima ao escutelo que alcança o quarto basal, e três da base ao ápice elitral.

Cabeça com pontos finos, rasos e densos e pêlos curtos e dourados. Olhos sem dimorfismo sexual; lobos oculares superiores com oito fileiras de omatídios; lobos inferiores não alcançam a face ventral da cabeça. Mandíbulas (Fig. 12) sem dimorfismo sexual, com carena dorsal nos $2 / 3$ basais e dois dentes no bordo interno. Genas triangulares, com cerca de um terço do diâmetro do lobo ocular inferior. Palpos labiais e maxilares (Figs. 13, 16) moderadamente desenvolvidos, ambos com artículos cilíndricos; os apicais atenuados na base e no ápice; palpos labiais com artículo apical quase tão longo quanto o anterior; palpos maxilares com o segundo artículo $1 / 3$ mais longo que o apical. Antenas ultrapassam os ápices elitrais no antenômero IX. Sistema porífero no quarto apical do III e ao longo da margem lateral externa dos antenômeros IV-XII. Escapo com pontos finos, densos e pêlos curtos, dourados; III-V com pêlos longos na face ventral; IV-XII com pêlos esparsos e pouco evidentes; antenômero III (Fig. 1) cerca de 1,5 vezes o comprimento do escapo e com projeção espiniforme no ápice externo; III-XII com pontos esparsos e subiguais em comprimento; XII com ápice estreitado e curvado.

Lados do protórax com três tubérculos pretos. Pronoto subglabro, com pontos finos e grossos, rasos e moderadamente densos e com um par de tubérculos pretos quase laterais, logo após o meio; margem anterior arredondada. Prosterno deprimido transversalmente, com pontos mais grossos e adensados que no pronoto e pêlos curtos, esparsos e amarelados. Processo prosternal truncado, com tubérculo desenvolvido no ápice. Processo mesosternal plano. Pernas com pontos finos, densos e pêlos curtos, densos e dourados. Fêmures (Fig. 25) cilíndricos. Esternito V (Fig. 28) com a margem apical sinuosa.

Terminália: esternito VIII (Fig. 29) transverso, margem apical sinuosa e arredondada aos lados; apófise esternal tão longa quanto o esternito. Arco ventral (Fig. 34) em forquilha, apófise com cerca da metade do comprimento dos braços; ápice da apófise reto. Arco dorsal reduzido, membranoso, pigmentado nas regiões laterais. Tégmen (Fig. 39) com região distal alargada e dividida em parâmeros cilíndricos com ápices arredondados e pêlos curtos; peça anelar arredondada. Lobo médio (Fig. 44): lobo ventral ligeiramente mais curto que o dorsal; ambos com ápice truncado; apófises basais ligeiramente mais longas que a porção apical. Saco interno com duas peças transversas esclerotizadas.

Fêmea. Palpos labiais e maxilares com artículos engrossados para o ápice e mais curtos do que nos machos; artículos apicais expandidos para o ápice. Antenas alcançam o quarto apical dos élitros; antenômeros III-IV com projeção aguçada no ápice externo; III com o dobro do comprimento do IV; IV-VIII subiguais em comprimento; IX-XII gradualmente crescentes. Esternito VIII (Figs. 64-68) com apófise estreita exceto o terço apical expandido, com cerca de três vezes a região mediana e ápice truncado; margem apical distintamente sinuosa na região mediana; pêlos aciculares mais curtos que os conchoidais, estes sem ranhuras; pêlos espatulados com ranhuras na região dorsal. Ovipositor (Fig. 50) com lobos laterais ligeiramente divergentes e região basal estreitada aos lados; espermateca curva na região basal; glândula espermatecal mais curta que a espermateca.

Variabilidade. Podem apresentar mancha preta mediana próximo à margem posterior do pronoto.

Dimensões em mm, respectivamente, macho/fêmea. Comprimento total, 25,5/38,2-18,9/40,5; comprimento do protórax, 4,0/6,7-2,9/6,3; maior largura do protórax, 5,4/7,9-4,0/ 8,5; comprimento do élitro, 18,6/27,9-14,0/30,7; largura umeral, $6,0 / 9,2-4,5 / 9,7$.

Material-tipo. Espécie descrita do Brasil e o exemplar-tipo não foi localizado.

Discussão. Coccoderus novempunctatus é grupo-irmão de C. bisignatus + (Fig. 91) por compartilharem as seguintes apomorfias: presença de franja de pêlos na margem externa do antenômero III $\left(6_{1}\right)$; pronoto com a margem anterior arredondada (13 $)$; processo prosternal com tubérculo (16 $)$; esternito V com a magem apical sinuosa $\left(27_{1}\right)$. C. 

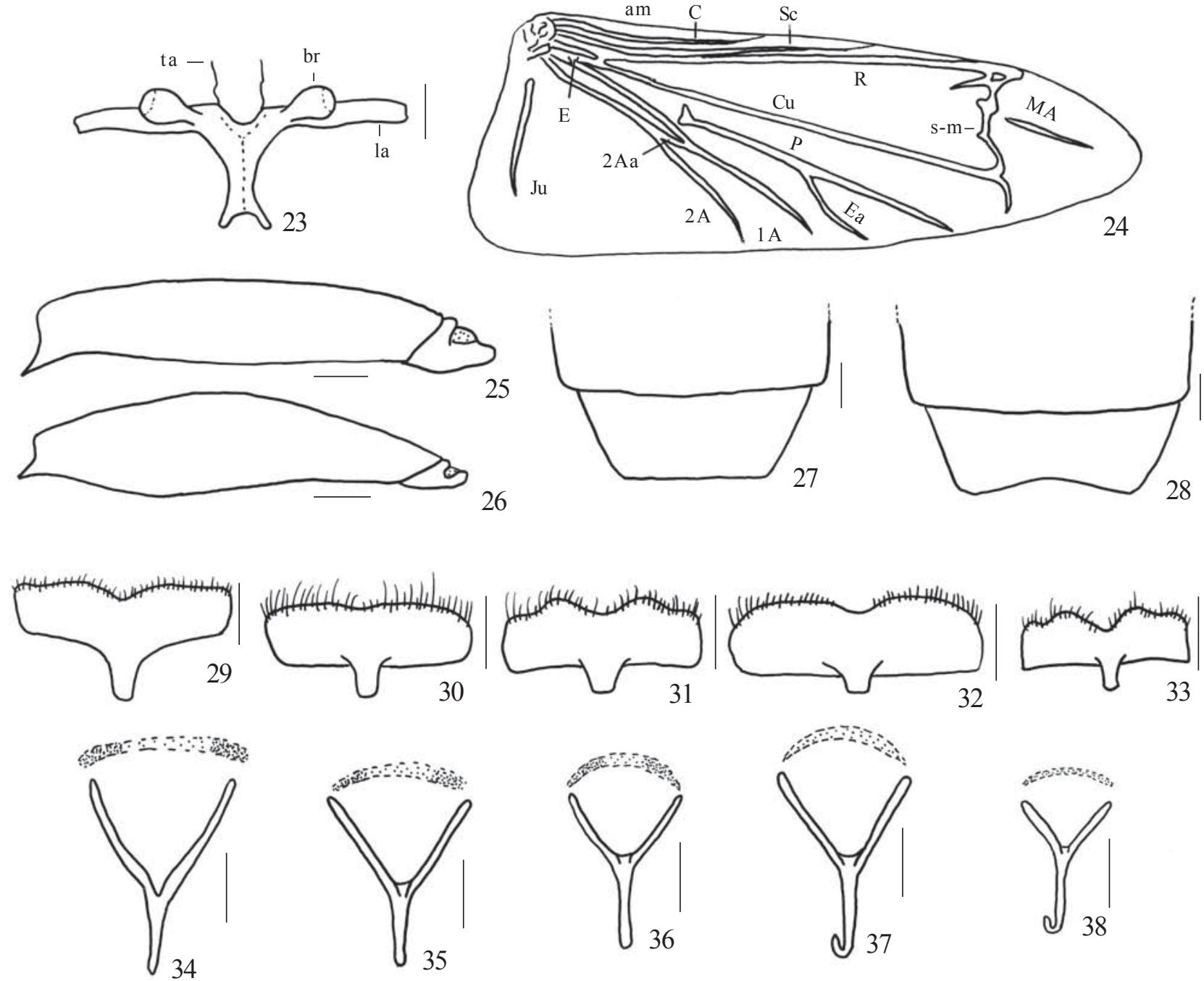

Figs. 23-38. Coccoderus novempunctatus, 23, metendosternito, 24, asa, 25, metafêmur; 26, C. sicki, metafêmur. Esternito V, macho: 27, C. sexguttatus; 28, C. novempunctatus. Esternito VIII, macho: 29, C. novempunctatus; 30, C. sexmaculatus; 31, C. speciosus; 32, C. longespinicornis; 33, C. sicki. Arco ventral e dorsal: 34, C. novempunctatus; 35, C. sexmaculatus; 36, C. speciosus; 37, C. longespinicornis; 38, C. sicki; am=aba membranosa; $\mathrm{br}=$ braço lateral; $\mathrm{C}=\mathrm{Costa} ; \mathrm{Cu}=$ Cubital; $\mathrm{E}=$ Empusal; $\mathrm{Ea}=$ ramo a da Empusal; Ju = Jugal; la = lâmina; MA = Média-Anterior; $\mathrm{P}$ $=$ Plical; $\mathrm{R}=$ Radial; $\mathrm{Sc}=$ Subcosta; $\mathrm{s}-\mathrm{m}=$ transversa; ta=tendão anterior; $1 \mathrm{~A}=1^{\mathrm{a}}$ anal; $2 \mathrm{~A}=2^{\mathrm{a}}$ anal; $2 \mathrm{Aa}=$ ramo da $2 \mathrm{~A}$. Barra $=1 \mathrm{~mm}$.

novempunctatus apresenta as seguintes autapomorfias: mandíbulas, no bordo interno, com dois dentes $\left(4_{1}\right)$; antenômero III mais curto que o IV $\left(7_{1}\right)$; lados do protórax com três pares de tubérculos $\left(11_{2}\right)$; élitros sem manchas ebúrneas $(190)$.

Distribuição geográfica (Fig. 93). BRASIL (Goiás, Mato Grosso, Distrito Federal, Rio Grande do Norte ao Rio Grande do Sul), PARAGUAI, ARGENTINA (Misiones, Salta, Santiago del Estero, Chaco, Entre Ríos, Buenos Aires), URUGUAI. Ocorre praticamente em toda a extensão da Mata Atlântica e ainda nas Florestas Tropicais do Brasil Central.

Imaturos. Bondar (1915) ilustrou a larva, sem descrevê-la, e a considerou semelhante à de Diploschema rotundicolle (Audinet-Serville, 1834) “... pelo seu segmento thoracico, porém faltam-lhe os espinhos no segmento anal.”
Biologia. Bondar (1915) observou, em Delonix regia (Bojer) (Caesalpiniaceae) (Flamboyant), que a larva de $C$. novempunctatus se desenvolve em madeira viva, escavando uma longa galeria que desce dos ramos finos aos mais grossos até o tronco e neste, a galeria feita pela larva é realizada em espiral e em diversos planos. Silva \& Almeida (1941) descreveram e ilustraram os estragos causados pela larva em Caesalpinia echinata Lamarck (Caesalpiniaceae) (pau-brasil) e observaram que a larva conserva a galeria limpa retirando toda a serragem através de orifícios que são abertos na casca a diversas alturas ou distâncias e, ao atingir seu total desenvolvimento, deriva da direção geral axial em curvas que se aproximam da região cortical, onde prepara a câmara pupal, vedando a entrada com raspas de madeira que é comprimida em massa compacta com o auxílio da serragem. O ciclo de vida foi estimado em aproximadamente dois anos. Di Iorio (1998) incluiu novas informações sobre plantas hospedeiras, biologia 
e descreveu a arquitetura das galerias das larvas em quatro plantas hospedeiras.

Plantas hospedeiras. Segundo Monné (2001) as seguintes plantas hospedeiras foram citadas para $C$. novempunctatus: Caesalpinia echinata, C. peltophoroides, Carpotroche brasiliensis, Cassia ferruginea, C. fistula, C. grandis, C. macranthera, C. nodosa, C. reticulata, C. strobilacea, Delonix regia, Tamarindus indica (Caesalpiniaceae), Acacia dealbata, A. decurrens, A. decurrens mollissima, A. praecox, Enterolobium contortisiliquum, Inga affinis, I. sessilis, I. uruguensis, I. vera, Mimosa detinens, Piptadenia communis (Mimosaceae) e Blepharistemma tweediei (Myrtaceae).

Material examinado. BRASIL, Maranhão: Imperatriz, fêmea, XII.1998, L. F. Reys col. (MNRJ); Rio Grande do Norte: Lages, fêmea, 24.II.1980, S. M. Delfino (MNRJ); Goiás: Cabeceiras (Lagoa Formosa), fêmea, 24-27.XI.1966, Lenko \& Pereira col. (MZSP); Mineiros, fêmea, X.1989, P. R. Magno col. (MNRJ); Niquelândia, fêmea, X.1986, L. C. Alvarenga col. (MNRJ); Distrito Federal: Planaltina, macho, 27.X.1988, V. O. Becker col. (CPAC); Mato Grosso: Utiariti, Rio Papagaio, fêmea, 1-12.XI.1966, Lenko \& Pereira col. (MZSP); Rio Verde, fêmea, XI.1960, A. Maller col. (MNRJ); Chavantina, fêmea, XI.1946 (MNRJ); Bahia: Estr. Rio-Bahia, km 965, Motel da Divisa, 960m, XI.1974, Seabra \& Roppa col. (MNRJ); Minas Gerais: Serra do Caraça (1380 m), fêmea, XI.1961, Kloss, Lenko, Martins \& Silva col. (MZSP); 2 fêmeas, 30.XI.1972, Exp. Mus. Zool. (MZSP); Uberlândia, macho, X.1962, Exp. Dep. Zool. (MZSP); Viçosa (648m), fêmea, XII.1957, E. Amante col.(MZSP); fêmea, XI.1954, U. Martins col. (MZSP); Curvelo, fêmea, 30.XI.1986, Eraldo col. (MZSP); Teófilo Otoni, 3 fêmeas, X.1971, S. P. Nascimento (MNRJ); Barbacena, fêmea, 16.XI.1959 (MNRJ); Espirito Santo: Matilde, fêmea, 1940, A. Maller col. (MNRJ); Santa Tereza, macho, 4.XII.1966, c. T. \& C. Elias col. (DZUP); Rio de Janeiro: Rio de Janeiro (Jardim Botânico), fêmea, 16.X.1942 (MZSP); (Corcovado), macho, IX.1961, Alvarenga \& Seabra col. (MNRJ); Estrada Rio-São Paulo, km 47, fêmea, X.1944 (MZSP); macho, 1.X.1949, D. Mendes col. (MZSP); Itatiaia, fêmea, XI.1962, Zajciw col. (MNRJ); São Paulo: São Paulo (Ipiranga), 2 fêmeas, 20.XII.1938, F. Lane col. (MZSP); Barueri, fêmea, 15.XII.1961, K. Lenko col. (MZSP); Guarulhos, XI1963, F. M. Oliveira col. (MZSP); Atibaia, fêmea, 3.XI.1969 (MZSP); Itu (Fazenda Pau d'Alho), fêmea, 15.XI.1965, U. Martins col. (MZSP); Marília, fêmea, I.XI.1945, H. Zellibor col. (MNRJ); Paraná: Foz do Iguaçu, fêmea, 7.XII.1966 (MNRJ); Santa Catarina: Joinville, fêmea, IV.1956, Dirings col. (MZSP); Nova Teutônia, fêmea, XI.1941, F. Plaumann col. (MNRJ). ARGENTINA. Salta: Cerro San Bernardo, fêmea, XII.1942, Martinez col. (MNRJ).

Coccoderus bisignatus Buquet, 1840

(Figs. 2, 82, 91-93)

Coccoderus bisignatus Buquet, 1840: 294; Monné, 1994: 10; Tavakilian \& Monné, 2002: 20, figs. 13, 14.

Macho. Colorido geral alaranjado. Cabeça e protórax castanho-avermelhado. Élitros transparentes e amarelos exceto na base, alaranjados; com um par de manchas ebúrneas próximas à base.

Cabeça com pontuação finíssima, densa e rasa e pubescência esparsa e amarelada. Olhos sem dimorfismo sexual; lobos oculares superiores com dez fileiras de omatídios; lobos inferiores não alcançam a face ventral da cabeça. Mandíbulas com um dente mediano no bordo interno. Genas triangulares, com ápices arredondados e com cerca de um terço do diâmetro do lobo ocular inferior. Palpos labiais e maxilares moderadamente desenvolvidos, ambos com artículos cilíndrico-alongados; artículo apical dos labiais com comprimento subigual ao do anterior; palpos maxilares com segundo artículo pouco mais longo que o terceiro e subigual ao apical. Antenas ultrapassam os ápices elitrais no antenômero IX. Sistema porífero, nos antenômeros IV-XII, ocupa toda superfície e no III apenas o terço apical. Escapo com pontos finos e densos e pêlos curtos, densos e amarelados. Antenômeros III-XII com pêlos esparsos e amarelados; III (Fig. 2) cerca de 1,5 vezes o escapo e sem espinho no ápice; IV-XII com comprimentos subiguais; XII estreitado e curvado no ápice.

Protórax com pontos rasos, irregulares e pubescência curta, esparsa e amarelada, mais aparente no prosterno. Pronoto com a margem anterior arredondada. Prosterno deprimido transversalmente. Processo prosternal truncado e com tubérculo desenvolvido no ápice. Processo mesosternal plano. Pernas com pontos finos e densos e pêlos curtos, densos e amarelados. Fêmures cilíndricos. Esternito V com a margem apical sinuosa.

Fêmea. Palpos labiais e maxilares com artículos engrossados e mais curtos do que os do macho; artículos apicais expandidos para o ápice. Antenas alcançam o quarto apical dos élitros; antenômero III cerca do dobro do comprimento do IV; IV-XI subiguais; XII um terço mais longo que o XI. Protórax com pontuação mais evidente.

Dimensões em mm, respectivamente, macho/fêmea. Comprimento total, 39,0/35,7-43,6; comprimento do protórax, 7,0/6,2-7,1; maior largura do protórax, 9,2/8,2-9,6; comprimento do élitro, 27,8/25,2-31,5; largura umeral, 9,8/9,5-11,6.

Material-tipo. Holótipo macho (MNHN) de Cayenne, Guiana Francesa, examinado por meio do diapositivo feito por J. S. Moure (DZUP).

Discussão. C. bisignatus é grupo-irmão do clado $C$. sexmaculatus + (Fig. 91) pelos seguintes caracteres: palpos moderadamente alongados $\left(5_{1}\right)$; antenômero III sem projeção espiniforme ( $\left(8_{0}\right)$. Ver discussão em C. biguttatus.

Distribuição geográfica (Fig. 93). SURINAME, GUIANA FRANCESA, BRASIL (Amazonas). Ocorre na Floresta Amazônica.

Material examinado. GUIANA FRANCESA, Haute Courcibo: fêmea, 16.VII.1990 (piégeage lumineux) J. M. Baloup col. (MNHN); Piste de St-Elie pk 21, macho, 10.X.1991 (piégeage lumineux), Dominique Peugnet col. (MNHN). BRASIL, Amazonas: Novo Airão, Parque Nacional Jaú, baixo Rio Jaú ( $\left.1^{0} 59^{\prime} \mathrm{S}-61^{0} 45^{\prime} \mathrm{W}\right)$, macho, 30.IV 01.V.1995, C. S. Motta et al. col. (INPA); Rio Purus, macho, S. M. Klages col. (MZSP); Tefé, fêmea, IX.1959, R. Carvalho col. (MNRJ).

Coccoderus sexmaculatus Buquet, 1840

(Figs. 3, 14, 17, 19, 20, 30, 35, 40, 45, 49, 51, 57, 58, 69-71, 83,91-93)

Coccoderus sexmaculatus Buquet, 1840: 295; Monné, 1994: 11.

Macho. Colorido geral alaranjado a castanho-alaranjado. Élitros opacos; com três pares de manchas ebúrneas desenvolvidas, distância entre as manchas cerca da metade do comprimento de uma mancha. 

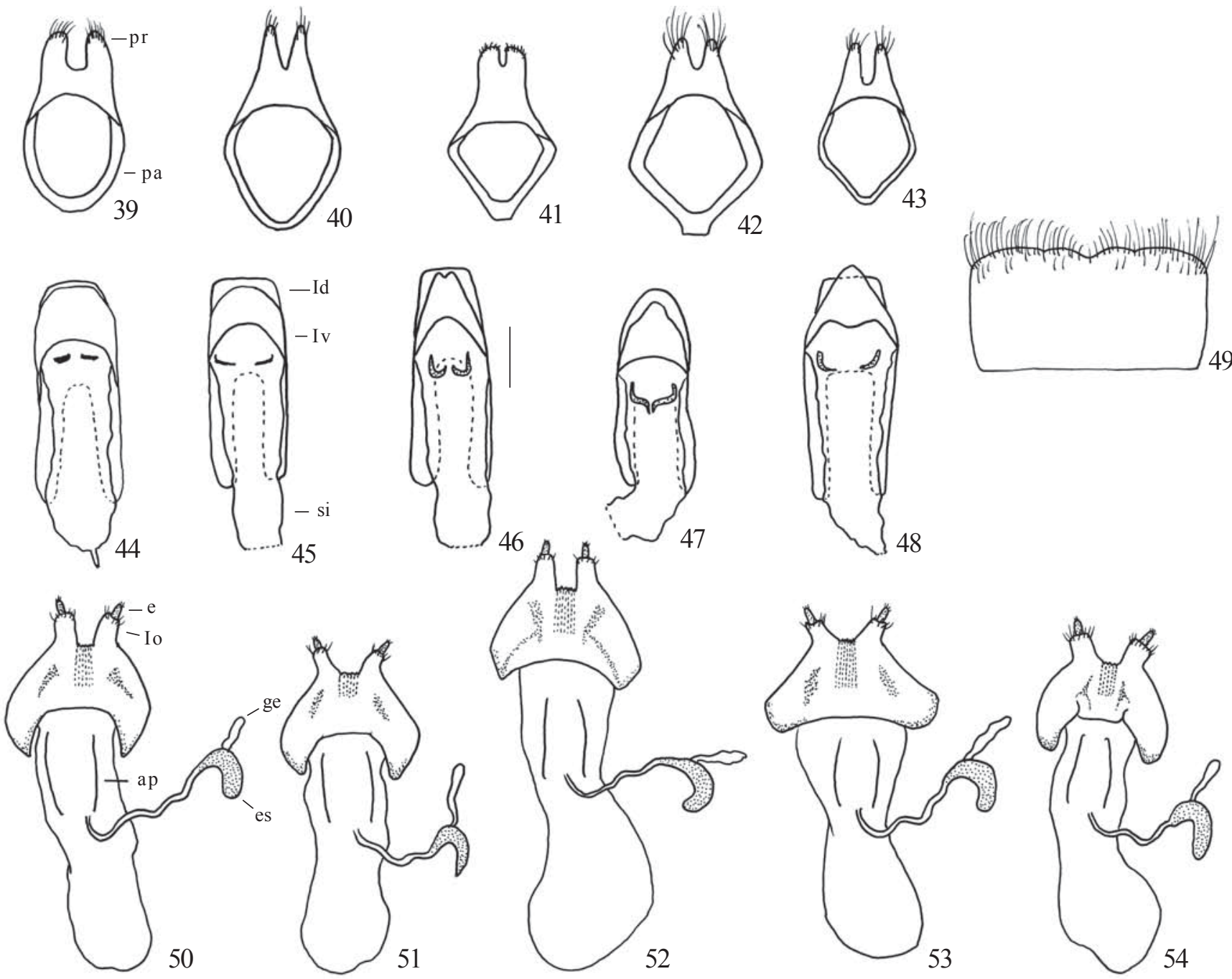

Figs. 39-54. Tégmen: 39, Coccoderus novempunctatus; 40, C. sexmaculatus; 41, C. speciosus; 42, C. longespinicornis; 43, C. sicki. Lobo médio: 44, C. novempunctatus; 45, C. sexmaculatus; 46, C. speciosus; 47, C. longespinicornis; 48, C. sicki. Tergito VIII, fêmea: 49, C. sexmaculatus. Ovipositor: 50, C. novempunctatus; 51, C. sexmaculatus; 52, C. speciosus; 53, C. longespinicornis; 54, C. sicki; ap=apódema; e=estilo; es=espermateca; ge=glândula da espermateca; ld=lobo dorsal; lo=lobo lateral; lv=lobo ventral; pa=peça anelar; pr=parâmero; si=saco interno. Todas as figuras na mesma escala. Barra $=1 \mathrm{~mm}$

Cabeça com pontos finos, rasos e moderadamente densos e pêlos alaranjados, esparsos. Olhos com dimorfismo sexual; lobos superiores com sete fileiras de omatídios; lobos inferiores parcialmente divididos pelas genas (Fig. 58) e estendem-se em estreita fileira de omatídios até a face ventral da cabeça. Mandíbulas (Fig. 57) mais desenvolvidas que nas fêmeas, falciformes e com um dente mediano no bordo interno. Palpos labiais e maxilares (Figs. 14, 17) desenvolvidos, ambos com artículos cilíndrico-alongados; artículo apical dos labiais com comprimento subigual ao do anterior; segundo artículo dos maxilares pouco mais longo que o terceiro e subigual ao apical. Antenas ultrapassam os ápices elitrais no antenômero VII. Sistema porífero no quarto apical dos antenômeros III-IV e ao longo da margem lateral externa dos V-XII. Escapo com pontos finos, densos e pêlos curtos, densos e amarelados; antenômeros III-V com pêlos longos e moderadamente densos; VI-XII com pêlos longos, esparsos e amarelados; III (Fig. 3) cerca do dobro do escapo e sem espinho no ápice; IV-XII subiguais em comprimento; XII estreitado e curvado no ápice.

Protórax subglabro e com pontos rasos pouco aparentes. Pronoto com a margem anterior arredondada e ligeiramente sinuosa. Prosterno deprimido transversalmente. Processo prosternal (Fig. 19) anguloso e tuberculado. Processo mesosternal plano. Pernas com pontos finos, rasos e esparsos e pêlos curtos, esparsos e amarelados. Fêmures ligeiramente fusiformes. Esternito V com a margem apical sinuosa.

Terminália: esternito VIII (Fig. 30) transverso, a margem apical ligeiramente sinuosa; apófise esternal cerca da metade do comprimento do esternito. Arco ventral (Fig. 35) em forquilha, apófise cerca da metade do comprimento dos braços; ápice da apófise reto. Arco dorsal reduzido, membranoso e pigmentado nas regiões laterais. Tégmen (Fig. 40) com parâmeros cilíndricos e estreitados para os ápices, estes arredondados e com pêlos curtos; peça anelar arredondada. 
Lobo médio (Fig. 45): lobo ventral mais curto que o dorsal; lobo dorsal com ápice truncado e ventral com ápice arredondado; apófises basais ligeiramente mais longas que a porção apical. Saco interno com duas peças esclerotizadas em forma de "L".

Fêmea. Lobos oculares superiores com oito fileiras de omatídios; lobos inferiores sem projeção para a região ventral da cabeça. Genas não projetadas em direção ao lobo ocular inferior. Mandíbulas menores que as dos machos. Palpos labiais e maxilares com artículos engrossados e mais curtos do que os do macho; artículos apicais expandidos para o ápice. Antenas alcançam o quarto apical dos élitros. Antenômeros III-V com ápice externo apenas anguloso; III cerca do dobro do comprimento do IV; IV-XII subiguais. Pronoto com pontuação rasa, densa e mais evidente. Esternito VIII (Figs. 69-71) com apófise estreita exceto o terço apical expandido, com cerca de três vezes a região mediana e ápice arredondado; margem apical sinuosa; pêlos aciculares mais curtos que os conchoidais; pêlos conchoidais e espatulados com ranhuras na região dorsal. Ovipositor (Fig. 51) com lobos laterais divergentes e margem basal estreitada e com ápice arredondado; espermateca curva e com ápice afilado; glândula espermatecal pouco mais longa que a espermateca.

Dimensões em mm, respectivamente, macho/fêmea. Comprimento total, 24,1/39,2-23,4/33,2; comprimento do protórax, 4,0/6,8-3,6/5,9; maior largura do protórax, 5,2/9,6-4,8/ 8,2 ; comprimento do élitro, 17,1/27,7-17,6/25,7; largura umeral, $5,8 / 9,8-5,7 / 9,0$.

Material-tipo. Holótipo macho (MNHN) proveniente do Brasil e examinado por meio do diapositivo feito por J. S. Moure (DZUP).

Discussão. As análises indicaram, C. sexmaculatus ou como grupo-irmão de C. amazonicus (Fig. 92) parentesco sustentado pela homoplasia: antenômero III com franja de pêlos na margem externa $\left(6_{1}\right)$, que ocorre como convergência em $C$. novempunctatus, ou como grupo-irmão de $C$. amazonicus + C. guianensis (Fig. 91), pelas sinapomorfias: lobo ocular inferior com prolongamento estreito para a região ventral da cabeça ( $\left.2_{1}\right)$; élitros com cerca de três vezes a distância entre as manchas ebúrneas medianas e posteriores em relação ao comprimento da mancha mediana $\left(20_{2}\right)$; metafêmures ligeiramente fusiformes $\left(24_{1}\right)$.

Coccoderus sexmaculatus difere das demais espécies do gênero pelas mandíbulas falciformes, com um dente mediano no bordo interno e pronoto com a margem anterior arredondada e ligeiramente sinuosa.

Distribuição geográfica (Fig. 93). BRASIL (Bahia, Goiás, Distrito Federal, Minas Gerais, Espírito Santo, Rio de Janeiro, São Paulo). Ocorre na Mata Atlântica e possivelmente em matas de galeria no Cerrado.

Material examinado. BRASIL, Bahia: Encruzilhada, Estrada RioBahia km 965 (Motel da Divisa), 10 machos, 16 fêmeas, XI.1972 Seabra \& Roppa col. (MNRJ); Goiás: Vianópolis, fêmea, X.1969, N. Tangerini (MNRJ); Distrito Federal: Planaltina, macho, 30.X.1989 (CPAC); Minas Gerais: Belo Horizonte, macho, X1952 (MZSP); Coromandel, macho, XI.1986, L. C. Alvarenga col. (MNRJ); Unai (Faz. Bolívia), fêmea, 22-24.X.1964, Exp. Dep. Zool. (MZSP); Espírito Santo: Fazenda Jerusalém, fêmea, 15.XI.1913 Zikan col. (MZSP);
Santa Tereza, fêmea, 27.XII.1966 C. Elias col. (DZUP); Rio de Janeiro: Itatiaia (1250m), fêmea, XII.1949, J. L. Lima col. (MZSP); Rio de Janeiro (Corcovado), 4 fêmeas, 6 machos, 27.XII.1962, Alvarenga \& Seabra col. (MNRJ); Teresópolis, macho, (MZSP).

\section{Coccoderus amazonicus Bates, 1870}

(Figs. 5, 55, 84, 91-93)

Coccoderus amazonicus Bates, 1870: 249; Monné, 1994: 10; Tavakilian \& Monné, 2002: 30, 31, 7 figs.

Macho. Colorido geral castanho-alaranjado. Ápices dos antenômeros e fêmures castanho-escuros. Élitros amarelados e transparentes; com três pares de manchas ebúrneas pequenas; distância entre as manchas cerca de três vezes o comprimento de uma mancha.

Cabeça com pontos finos, rasos e densos e com pêlos curtos e amarelados. Olhos com dimorfismo sexual; lobos inferiores parcialmente divididos pelas genas e estendem-se em estreita fileira de omatídios até a face ventral da cabeça. Mandíbulas (Fig. 55) com dimorfismo sexual; nos machos, desenvolvidas e com um dente no bordo interno. Palpos labiais e maxilares distintamente desenvolvidos, ambos com artículos cilíndrico-alongados; artículo apical dos labiais um terço mais curto que o anterior; segundo artículo dos maxilares um terço mais longo que o terceiro e este subigual ao apical. Antenas ultrapassam os ápices elitrais no ápice do antenômero VI; pontuação fina, esparsa e pêlos curtos, esparsos e amarelados exceto o III com pêlos longos e densos. Sistema porífero no terço apical do III e ao longo da margem lateral externa dos antenômeros IV-XII. Escapo com pontos finos e moderadamente densos; antenômero III (Fig. 5) cerca do dobro do escapo e sem espinho no ápice; III-XII com comprimentos subiguais; XII estreitado e curvado no ápice.

Protórax com pontos finos, rasos e densos. Pronoto com pêlos curtos, esparsos e amarelados, margem anterior arredondada. Prosterno deprimido transversalmente, com pêlos longos e curtos entremeados, esparsos e amarelados. Processo prosternal anguloso e com tubérculo apical. Processo mesosternal plano. Pernas com pontos finos e densos e pêlos curtos, densos e amarelados. Fêmures ligeiramente fusiformes. Esternito V sinuoso na margem apical.

Fêmea. Lobos oculares inferiores não alcançam a face inferior da cabeça. Genas triangulares com ápices arredondados, não projetadas em direção aos lobos oculares inferiores e com cerca de um terço do diâmetro do lobo ocular inferior. Mandíbulas mais curtas do que nos machos. Palpos labiais e maxilares com artículos engrossados e mais curtos que nos machos; artículos apicais expandidos para o ápice. Antenas alcançam o quarto apical dos élitros, antenômeros III-V com ápices externos apenas angulosos; III cerca de três vezes o comprimento do IV; IV-XI subiguais; XII 1,5 vezes o XI.

Dimensões em mm, respectivamente, macho/fêmea. Comprimento total, 29,5/31,5; comprimento do protórax, 5,0/ 5,2 ; maior largura do protórax, 6,6/7,2; comprimento do élitro, 21,2/23,2; largura umeral, 7,9/8,2.

Material-tipo. Holótipo macho (MNHN) de Tapajós, Pará, Brasil, estudado por meio de diapositivo feito por J. S. Moure (DZUP). 

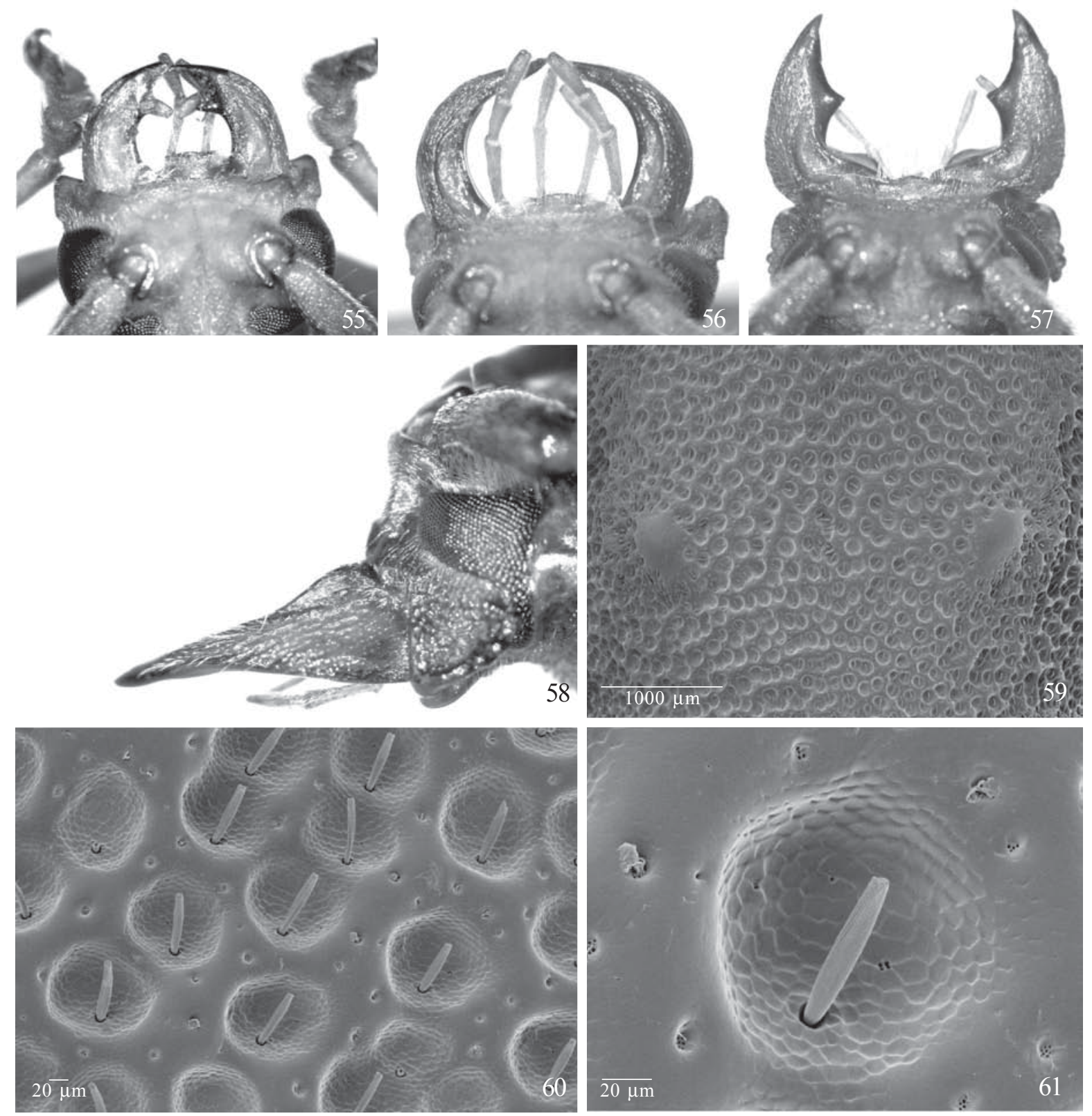

Figs. 55-61. Mandíbulas: 55, C. amazonicus; 56, C. guianensis; 57, C. sexmaculatus. Detalhe do lobo ocular inferior e gena: 58, C. sexmaculatus. Pontuação do pronoto, C. speciosus: 59, aspecto geral (50x); 60-61, detalhe dos pontos setígeros e microesculturados (300x e 900x, respectivamente).

Discussão. C. amazonicus é grupo-irmão de C. guianensis (Fig. 91) por compartilharem os palpos maxilares e labiais distintamente alongados $\left(5_{2}\right)$. Tavakilian \& Monné (2002: 31, fig. 51) consideraram estas espécies muito semelhantes e distinguiram-nas principalmente pelas mandíbulas e manchas ebúrneas elitrais. Em C. amazonicus, as mandíbulas, em ambos os sexos, apresentam um dente no bordo interno e a região entre o dente e a base é escavada; as manchas ebúrneas nos élitros têm aspecto arredondado. Em C. guianensis, as mandíbulas, nos machos, são falciformes e sem dente no bordo interno e, nas fêmeas, apresentam um dente no bordo interno; as manchas ebúrneas têm aspecto ovalado.

Distribuição geográfica (Fig. 93). BRASIL (Pará, Minas
Gerais). A escassez de material e, conseqüentemente, de dados de distribuição impossibilita conjecturar sobre a formação vegetal à qual esta espécie estaria relacionada.

Material examinado. BRASIL, Minas Gerais: Buritis (Primeira cachoeira, Rio Urucuia), macho, 2-4.XI.1964, Exp. Dep. Zool. (MZSP); (Ribeirão Confins), fêmea, 29-31.X.1964, Exp. Dep. Zool. (MZSP).

Coccoderus guianensis Tavakilian \& Monné, 2002

(Figs. 4, 56, 85, 91-93)

Coccoderus guianensis Tavakilian \& Monné, 2002: 27, figs. 17, 18, 51.

Macho. Colorido geral castanho-alaranjado. Ápices dos 
antenômeros e fêmures castanho-escuros. Élitros transparentes e amarelados exceto no terço basal, alaranjados; com três pares de manchas ebúrneas pequenas, distância entre as manchas cerca de três vezes o comprimento de uma mancha.

Cabeça com pontos finos, irregulares e densos e pêlos curtos e amarelados. Olhos com dimorfismo sexual; lobos superiores com sete fileiras de omatídios; lobos inferiores parcialmente divididos pelas genas e estendem-se em estreita fileira de omatídios até a face ventral da cabeça. Mandíbulas (Fig. 56) com dimorfismo sexual; nos machos, falciformes e distintamente desenvolvidas. Palpos labiais e maxilares distintamente desenvolvidos, ambos com artículos cilíndricoalongados; artículo apical dos labiais um terço mais curto que o anterior; segundo artículo dos maxilares um terço mais longo que o terceiro e este subigual ao apical. Antenas ultrapassam os ápices elitrais no antenômero VII, com pontos finos e esparsos e pêlos curtos, esparsos e amarelados. Sistema porífero no terço apical do III e ao longo da margem lateral externa dos antenômeros IV-XII; antenômero III (Fig. 4) cerca do dobro do escapo e sem espinho no ápice; IV cerca de $2 / 3$ do III; IV-XII com comprimentos subiguais; XII estreitado e curvado no ápice.

Protórax com pontos rasos, densos e irregulares. Pronoto com pêlos curtos, esparsos e amarelados; margem anterior arredondada. Prosterno deprimido transversalmente e com pêlos longos, esparsos e amarelados. Processo prosternal anguloso e tuberculado no ápice. Processo mesosternal plano. Pernas com pontos finos, densos e pêlos curtos, densos e amarelados. Fêmures ligeiramente fusiformes. Esternito V sinuoso na margem apical.

Fêmea. Lobos oculares superiores com nove fileiras de omatídios. Genas triangulares, com ápices arredondados e com cerca de um terço do diâmetro do lobo ocular inferior. Mandíbulas moderadamente alongadas, não falciformes e com um dente mediano aguçado no bordo interno. Palpos labiais e maxilares com artículos engrossados e mais curtos do que nos machos; artículos apicais expandidos para o ápice. Antenas apenas alcançam o terço ou o quarto apical dos élitros, antenômeros III-V com ápices externos apenas angulosos; III cerca do triplo do IV; IV-VIII e IX-XI subiguais; XII 1,5 vezes o IV. Pronoto com pontos mais evidentes.

Dimensões em mm, respectivamente, macho/fêmea. Comprimento total, 34,2-32,5; comprimento do protórax, 6,35,2; maior largura do protórax, 9,0-7,5; comprimento do élitro, 23,5-24,0; largura umeral, 9,4-8,4.

Material-tipo. Holótipo macho (MNHN) da Guiana Francesa. Foram examinados três parátipos, um macho e duas fêmeas (MNRJ).

Discussão. Vide discussão em C. amazonicus.

Distribuição geográfica (Fig. 93). GUIANA FRANCESA e BRASIL (Amapá). Espécie relacionada à Floresta Amazônica.

Material examinado. GUIANA FRANCESA, Layon de la Ferme Vidal, macho (parátipo), 6.VII.1984, G. Tavakilian col. (MNRJ); pk 40 route de Kaw, fêmea (parátipo), 24.X.1984, S. Boucher col. (MNRJ); Montjoly, fêmea (parátipo), 8.VII.1985, Jean-Louis Duprey (MNRJ). BRASIL, Amapá: Oiapoque, fêmea, IX.1959, Viana col. (MNRJ).
Coccoderus biguttatus Martins, 1985

(Figs. 6, 86, 91, 92, 94)

Coccoderus biguttatus Martins, 1985: 173; Monné, 1994: 10.

Macho. Colorido geral alaranjado. Élitros transparentes amarelados exceto na base, alaranjados; com um par de manchas ebúrneas próximas à base e três costas ebúrneas bem indicadas.

Cabeça com pontos finos, densos e irregulares e pubescência esparsa e esbranquiçada. Olhos sem dimorfismo sexual; lobos oculares superiores com oito fileiras de omatídios; lobos inferiores não alcançam a face ventral da cabeça. Mandíbulas com um dente no bordo interno. Genas triangulares, com ápices aguçados e com cerca de um terço do diâmetro do lobo ocular inferior. Palpos labiais e maxilares moderadamente desenvolvidos, ambos com artículos cilíndricos; artículos apicais atenuados na base e no ápice; artículo apical dos labiais com comprimento subigual ao anterior; o segundo dos maxilares mais longo que o apical. Antenas ultrapassam os ápices elitrais no antenômero IX. Sistema porífero no terço apical do III e ao longo da margem externa dos antenômeros IV-XII. Escapo com pontos finos e densos e pêlos curtos, densos e amarelados; antenômeros IIIXII com pêlos esparsos e amarelados; III (Fig. 6) cerca do dobro do escapo e com espinho curto e curvo no ápice externo; IV-XII com comprimentos subiguais; XII estreitado no ápice e não encurvado.

Protórax com pubescência curta, esparsa e pouco aparente e superfície com pontos densos, confluentes e microesculturados. Pronoto com margem anterior truncada. Prosterno deprimido transversalmente. Processo prosternal anguloso e sem tubérculo. Élitros com região látero-basal deprimida. Ápices elitrais apenas com espinho sutural. Pernas com pontos finos e densos e pêlos curtos, densos e esbranquiçados. Fêmures cilíndricos; ápices internos dos meso- e metafêmures com aba aguçada. Esternito V com a margem apical ligeiramente sinuosa.

Fêmea. Palpos labiais e maxilares com artículos engrossados e mais curtos que nos machos; artículos apicais expandidos para o ápice. Antenas alcançam o terço apical dos élitros; III cerca de 2,5 vezes o comprimento do IV; IV-XI subiguais; XII um terço mais longo que o XI.

Dimensões em mm, respectivamente, macho/fêmea. Comprimento total, 24,2/23,2-31,3; comprimento do protórax, 4,1/3,6-5,0; maior largura do protórax, 5,3/4,9-6,8; comprimento do élitro, 17,4/17,2-23,1; largura umeral, 6,4/5,9-7,7.

Material-tipo. Holótipo macho e parátipos, fêmea (CMNH) e macho (MZSP), de Província del Sara, Santa Cruz, Bolívia. Parátipo macho (MZSP) examinado.

Discussão. Martins (1985) considerou C. biguttatus semelhante à $C$. speciosus e C. bisignatus. Neste estudo, $C$. biguttatus é grupo-irmão de C. speciosus (Fig. 91) pelas seguintes apomorfias: pronoto com pontos microesculturados (12 $)$; élitros com depressão látero-basal (21 ); ápice dos élitros 

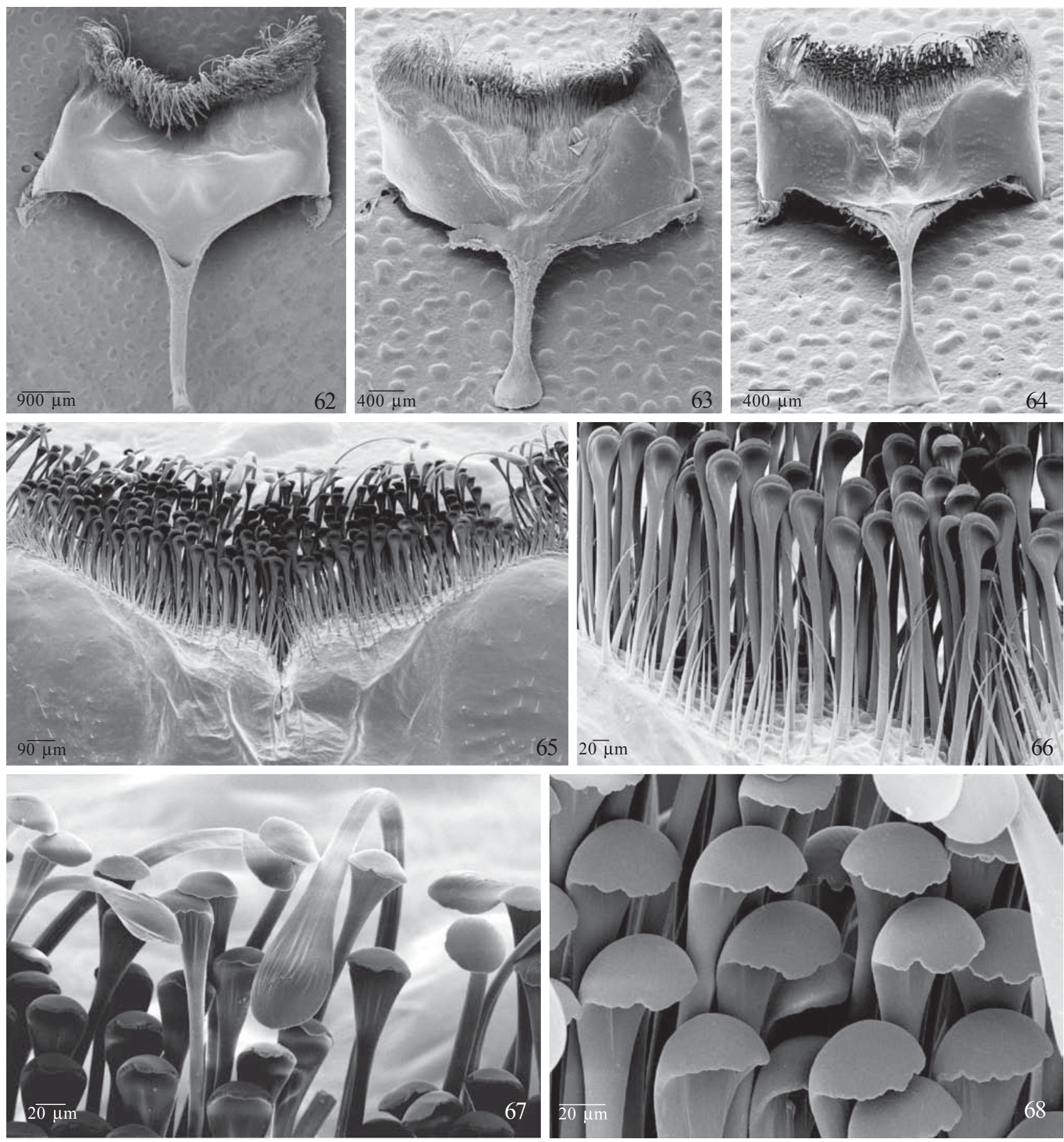

Figs. 62-68. Esternito VIII, fêmea, aspecto geral. 62, Psygmatocerus wagleri (18x); 63, Spathopygus eburoides (25x); 64, Coccoderus novempunctatus (35x). C. novempunctatus: 65, detalhe da escova de pêlos (65x), 66, detalhe dos pêlos aciculares e conchoidais (300x), 67, detalhe dos pêlos espatulados (500x); 68, detalhe dos pêlos conchoidais (900x).

sem espinho lateral $\left(22_{1}\right)$; ápice interno dos mesofêmures com aba aguçada (23,); ápice interno dos metafêmures com aba aguçada $\left(26_{1}\right)$. C. biguttatus assemelha-se à C. bisignatus pela presença de apenas um par de manchas ebúrneas na base dos élitros, entretanto, pela análise cladística, não são proximamente relacionadas.

Distribuição geográfica (Fig. 94). BRASIL (Mato Grosso),
BOLÍVIA. Provavelmente relacionada a matas de galeria no Cerrado.

Material examinado. BRASIL, Mato Grosso: Diamantino (Alto Rio Arinos), fêmea, X.1979, O. Roppa, P. Magno, J. Becker col. (MNRJ); fêmea, X.1983, B. Silva col. (MNRJ); Pontes e Lacerda, fêmea, X.1988, O. Roppa, P. Magno, J. Becker col. (MNRJ); Rosário Oeste, macho, X.1960 (MNRJ). BOLÍVIA, Santa Cruz: Província del Sara, parátipo macho, Steinbach col. CM Acc. $\mathrm{n}^{\circ} 4552$ (MZSP). 
Coccoderus speciosus Gounelle, 1909

(Figs. 7, 31, 36, 41, 46, 52, 59-61, 72-74, 87, 91, 92, 94)

Coccoderus speciosus Gounelle, 1909: 606; Martins \& Monné, 1980: 337, 338 (syn.); Monné, 1994: 11.

Coccoderus teixeirai Lane, 1939: 74; 1950: 367, pl. 1, fig. 3.

Macho. Colorido geral castanho a castanho-avermelhado. Élitros opacos, com três pares de manchas ebúrneas margeadas por colorido castanho-escuro e a distância entre as manchas cerca de duas vezes o comprimento de uma mancha.

Cabeça com pontos finos, densos e com pêlos curtos e esbranquiçados. Olhos sem dimorfismo sexual; lobos oculares superiores com sete fileiras de omatídios; lobos inferiores não alcançam a face ventral da cabeça. Mandíbulas sem dimorfismo sexual e com um dente no bordo interno. Genas triangulares, com ápices arredondados e cerca de um terço do diâmetro do lobo ocular inferior. Palpos labiais e maxilares moderadamente desenvolvidos, ambos com artículos cilíndricos; artículos apicais atenuados na base e no ápice; artículo apical dos labiais com comprimento subigual ao anterior; o segundo dos maxilares mais longo que o apical. Antenas ultrapassam os ápices elitrais no antenômero IX. Sistema porífero no terço apical do III e ao longo da margem lateral externa dos antenômeros IV-XII. Escapo com pontos moderadamente grossos e densos e pêlos curtos, esparsos e amarelados; antenômeros III-XII com pêlos longos e esparsos e pontos finos e esparsos; III (Fig. 7) cerca de 1/3 mais longo que o escapo e com projeção espiniforme no ápice externo, mais curta que a largura do antenômero; IV cerca de 2/3 do III; IVXII com comprimentos subiguais; XII estreitado e curvado no ápice.

Protórax (Figs. 59-61) com pontos setígeros, microesculturados, grossos e densos; superfície, entre os pontos, lisa e com pequenos agrupamentos de micropontos. Pronoto com pêlos curtos, esparsos e esbranquiçados; margem anterior truncada. Prosterno deprimido transversalmente e com pêlos longos, esparsos e amarelados. Processo prosternal anguloso e tuberculado no ápice. Processo mesosternal plano. Élitros com a região látero-basal deprimida. Ápices elitrais apenas com espinho sutural. Pernas com pontos finos e densos e pêlos densos, curtos e amarelados. Fêmures cilíndricos. Ápices internos dos meso- e metafêmures com abas apenas projetadas.

Esternito V com a margem apical truncada. Terminália: esternito VIII (Fig. 31) transverso, margem apical bisinuosa; apófise esternal cerca da metade do comprimento do esternito. Arco ventral (Fig. 36) em forquilha, apófise subigual ao comprimento dos braços; ápice da apófise reto. Arco dorsal reduzido, membranoso e pigmentado na regiões laterais. Tégmen (Fig. 41) com região distal dividida em parâmeros alargados, curtos, com ápices arredondados e pêlos curtos; peça anelar angulosa na região mediana e com projeção apical pouco desenvolvida. Lobo médio (Fig. 46): lobo ventral mais curto que o dorsal; o ventral com ápice sinuoso e o dorsal, truncado; apófises basais ligeiramente mais longas que a porção apical. Saco interno com duas peças esclerotizadas em forma de gancho.
Fêmea. Palpos labiais e maxilares com artículos engrossados e mais curtos que nos machos; artículos apicais expandidos para o ápice. Antenas alcançam, no máximo, os ápices dos élitros; antenômeros III-V com ápices externos apenas angulosos; III cerca do dobro do IV; IV-XII subiguais. Esternito VIII (Figs. 72-74) com apófise expandida no ápice, cerca de quatro vezes mais larga que a região mediana e ápice arredondado; margem apical truncada; pêlos aciculares mais curtos que os conchoidais; pêlos conchoidais e espatulados com ranhuras na região dorsal. Ovipositor (Fig. 52), na região distal, com lobos laterais paralelos e margem basal obliquamente truncada; espermateca curva na região apical e arredondada no ápice; glândula espermatecal mais curta que a espermateca.

Dimensões em mm, respectivamente, macho/fêmea. Comprimento total, 24,6/32,5-22,0/33,7; comprimento do protórax, 4,2/5,6-3,5/5,2; maior largura do protórax, 6,0/7,9-4,8/ 7,$5 ;$ comprimento do élitro, 17,4/22,6-16,5/25,5; largura umeral, $6,5 / 9,4-6,2 / 9,2$.

Material-tipo. Três síntipos (MNHN), macho e duas fêmeas, de Jataí, Goiás, Brasil. Síntipo macho examinado por meio do diapositivo feito por J. S. Moure (DZUP).

\section{Discussão. Vide comentários em C. biguttatus.}

Distribuição geográfica (Fig. 94). BRASIL (Goiás, Bahia, Distrito Federal, Mato Grosso, Minas Gerais, São Paulo). Possivelmente relacionada ao domínio morfoclimático dos Cerrados, nas matas de galeria.

Material examinado. BRASIL, Goiás: Barra do Garça (Rio das Mortes, Fazenda Pequi), fêmea, 29.IX.1982, D. Teixeira col. (MNRJ); Caldas Novas, macho, fêmea, X.1982, Coimbra col. (MZSP); Campinaçu, fêmea, X.1992, O. Roppa col. (MNRJ); Jaraguá, macho, X.1934 (MZSP). Bahia: Rio das Contas, macho, XII.1976, O. Roppa col. (MNRJ). Distrito Federal: Planaltina, macho, 23.III.1977, V. O. Becker col. (CPAC). Mato Grosso: Camisão, macho, 18.X.1938, J. Teixeira de Freitas col. (MZSP).Coxim, fêmea, 1940 (MNRJ); fêmea, X.1969, A. Maller col. (MNRJ); Rio Verde, fêmea, XI.1959 (MZSP); 2 fêmeas, X.1960 (MNRJ); fêmea, 1962 (MNRJ); fêmea, X.1965, S. A. Fragoso col. (MNRJ); Rondonópolis, fêmea, XI.1965, S. A. Fragoso col. (MNRJ); Rosário Oeste, 3 fêmeas, XI-1960, A. Maller col. (MNRJ); fêmea, XII.1962 (MNRJ). Minas Gerais: Pirapora, fêmea, 29.X.1988, V. O. Becker col. (CPAC). São Paulo: Pirassununga, fêmea, I.1942, O. Schubart col. (MZSP).

Coccoderus longespinicornis Fuchs, 1964

(Figs. 8, 32, 37, 42, 47, 53, 75-77, 88, 91, 92, 94)

Coccoderus longespinicornis Fuchs, 1964: 7; Martins \& Monné, 1980: 337, 338 (syn.); Monné, 1994: 11.

Coccoderus spinosus Lane \& Martins, 1965: 17, fig. 1.

Macho. Colorido geral alaranjado. Ápices dos antenômeros e dos fêmures, castanhos. Élitros transparentes e amarelados exceto na base, alaranjados; com três pares de manchas ebúrneas pequenas; distância entre as manchas cerca de três vezes o comprimento de uma mancha.

Cabeça com pontos grossos, densos e rasos e pubescência esparsa e amarelada. Olhos sem dimorfismo sexual; lobos 

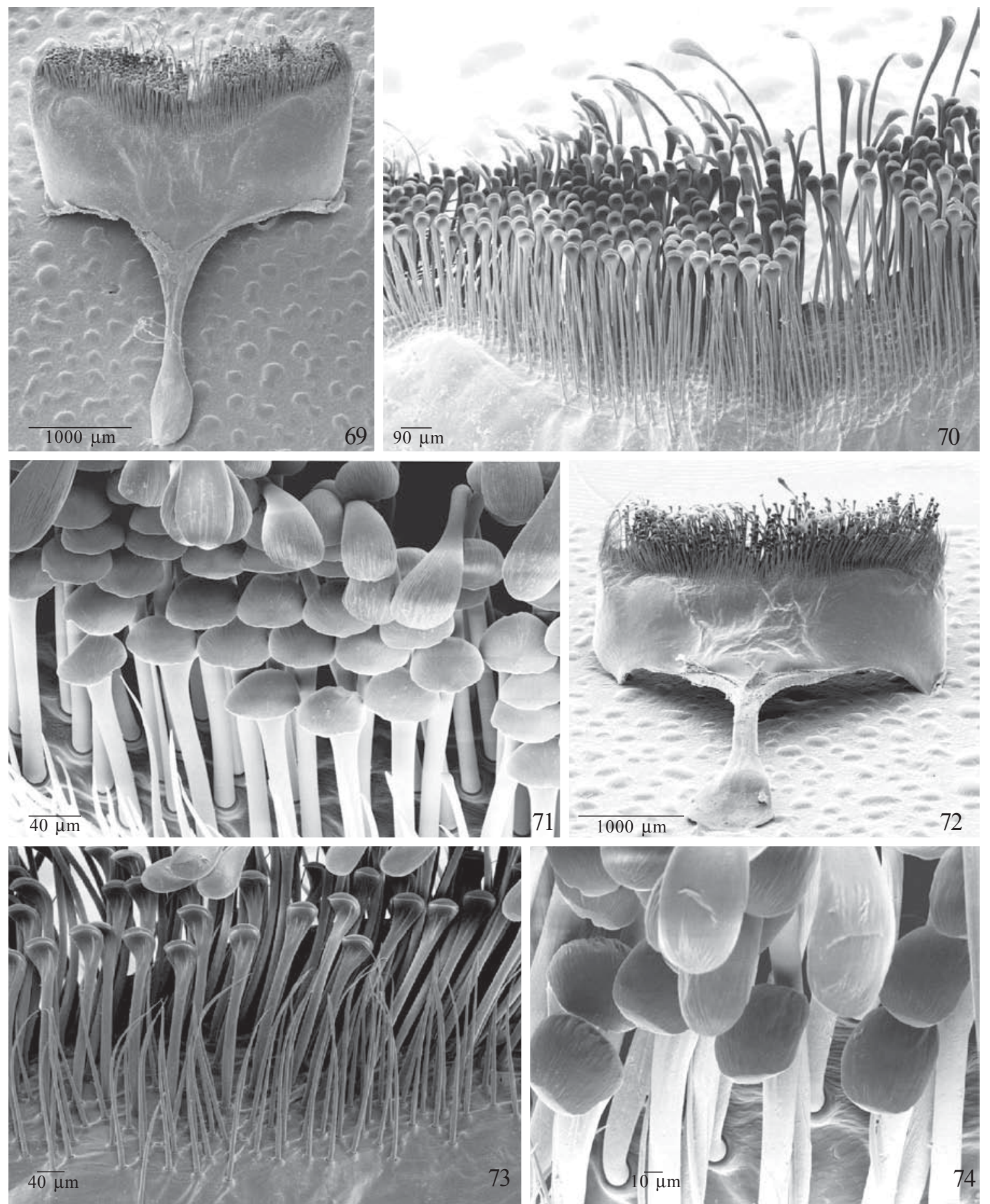

Figs. 69-74. Esternito VIII, fêmea. Coccoderus sexmaculatus: 69, aspecto geral (25x), 70, detalhe da escova de pêlos (100x), 71, detalhe dos pêlos aciculares e conchoidais (450x). Coccoderus speciosus: 72, aspecto geral (30x), 73, detalhe dos pêlos aciculares e conchoidais (180x), 74, detalhe dos pêlos espatulados e conchoidais (800x).

oculares superiores com onze fileiras de omatídios; lobos inferiores não alcançam a face ventral da cabeça. Mandíbulas com um dente mediano no bordo interno. Genas triangulares, com ápices arredondados e com cerca de um terço do diâmetro do lobo ocular inferior. Palpos labiais e maxilares moderadamente desenvolvidos, ambos com artículos cilíndricos; artículos apicais atenuados na base e no ápice; artículo apical dos labiais com comprimento subigual ao anterior; o segundo dos maxilares mais longo que o apical. Antenas com pubescência curtíssima e amarelada, ultrapassam os ápices elitrais no antenômero VIII. Sistema porífero, nos antenômeros III-XII, ocupa toda superfície. Escapo obcônico, 
com a margem apical truncada e com pontos finos e moderadamente densos; antenômeros III-XII engrossados (Fig. 88), pouco mais estreitos que o escapo; III-X com distinta projeção espiniforme no ápice externo, curva, tão longa quanto a largura do antenômero e que gradualmente diminui para os antenômeros apicais; III (Fig. 8) cerca de 1/3 mais longo que o IV; IV-XII com comprimento gradualmente decrescentes; XII cerca da metade do III, não estreitado nem curvado no ápice.

Protórax quase tão longo quanto largo; com pontos grosseiros, alveolados, profundos e densos. Pronoto glabro e com a margem anterior truncada. Prosterno com pubescência curta, esparsa e amarelada. Prosterno deprimido transversalmente. Processo prosternal anguloso e com tubérculo desenvolvido no ápice. Processo mesosternal convexo. Élitros cerca de 2,5 vezes o comprimento do protórax. Pernas com pontos finos, esparsos e pêlos curtos e esparsos. Fêmures cilíndricos; na região ventral com franja de pêlos longos e dourados. Esternito V com a margem apical ligeiramente sinuosa.

Terminália: esternito VIII (Fig. 32) transverso, margem apical com ligeira emarginação mediana e arredondada aos lados; apófise esternal curta, com cerca de $1 / 3$ do comprimento do esternito. Arco ventral (Fig. 37) em forquilha, comprimento da apófise subigual ao dos braços; ápice da apófise curva. Arco dorsal membranoso e em forma de lâmina recurva. Tégmen (Fig. 42) com região distal estreitada e dividida em parâmeros, estes atenuados para o ápice e com pêlos longos; peça anelar subangulosa e com projeção apical ligeiramente desenvolvida. Lobo médio (Fig. 47): lobo ventral mais curto que o dorsal, este com ápice arredondado e o ventral, acuminado; apófises basais ligeiramente mais longas que a porção apical. Saco interno com duas peças sinuosas esclerotizadas.

Fêmea. Palpos labiais e maxilares com artículos engrossados e mais curtos que nos machos; artículos apicais expandidos para o ápice. Antenas alcançam os ápices elitrais; sistema porífero no terço apical dos antenômeros III-IV e ao longo da margem lateral externa dos V-XII; III cerca de 1,5 vezes o comprimento do IV; IV-XII gradualmente decrescentes; XII cerca de um terço do comprimento do III. Fêmures sem franja de pêlos na região ventral. Esternito VIII (Figs. 75-77) com apófise expandida no ápice, com cerca de quatro vezes a largura da região mediana e ápice arredondado; margem apical ligeiramente sinuosa; pêlos aciculares mais curtos que os conchoidais; pêlos conchoidais e espatulados com ranhuras na região dorsal. Ovipositor (Fig. 53) com lobos laterais divergentes e margem basal arredondada; espermateca curva; glândula espermatecal ligeiramente mais curta que a espermateca.

Dimensões em mm, respectivamente, macho/fêmea. Comprimento total, 19,8/28,5-24,6/30,9; comprimento do protórax, 5,0/7,5-5,7/7,4; maior largura do protórax, 5,4/8,6-7,0/ 8,6 ; comprimento do élitro, 12,5/18,4-16,9/20,5; largura umeral, $5,0 / 9,7-7,5 / 10,4$.

Material-tipo. Holótipo e parátipo machos (ex-coleção Fuchs, atualmente coleção Herbert Schmid, Viena), de Rio Verde, Mato Grosso,
Brasil. Holótipo estudado por meio de diapositivo feito por J. S. Moure (DZUP).

Discussão. C. longespinicornis é grupo-irmão de $C$. sexguttatus + (Fig. 91) por compartilharem: antenômero III com projeção espiniforme maior que a largura do antenômero $\left(8_{2}\right)$; processo mesosternal convexo $\left(17_{1}\right)$; arco ventral com ápice curvo (30).

C. longespinicornis difere das demais espécies de Coccoderus por apresentar os antenômeros III-X com distinta projeção espiniforme no ápice externo; protórax com pontos grosseiros, elevados e irregulares; élitros cerca de 2,5 vezes o comprimento do protórax; fêmures, nos machos, com franja de pêlos longos na região ventral. Nas demais espécies de Coccoderus, a projeção espiniforme nos antenômeros, quando presente, ocorre apenas no antenômero III; o protórax pode apresentar pontos grossos mas não elevados e irregulares; os élitros são pelo menos quatro vezes o comprimento do protórax e os machos não apresentam franja de pêlos nos fêmures.

Distribuição geográfica (Fig. 94). VENEZUELA, PERU, BRASIL (Amazonas, Amapá, Pará, Piauí, Rondônia, Goiás, Distrito Federal, Mato Grosso, Mato Grosso do Sul, Minas Gerais). Espécie com ampla distribuição no Brasil, exceto na Mata Atlântica.

Material examinado. VENEZUELA, Caracas: km 107, macho, 16.VIII.1957, R. Lichy col. (MZSP); km 109, 2 machos, 24.VIII.1957, R. Lichy (MZSP). PERU, Cuzco: Quincemil, macho, X.1952, L. Peña (MZSP). BRASIL, Amapá: Serra do Navio (Igarapé Sucurijú) macho, X.1959, Bicelli col. (MZSP); Amazonas: Huytanahan (Rio Purus), macho, S. M. Klages col. (MZSP); Pará: Cachimbo, 2 machos, fêmea, 14-21.IX.1955, Travassos \& Oliveira col. (MNRJ); Piauí: Corrente, macho, 23-27.XI.1991, Amarante, Brandão, Cancello Martins \& Ponte col. (MZSP); Goiás: Jataí, Alto Araguaia, macho, 9.I.1969, S. A. Fragoso col. (MNRJ); Distrito Federal: Brasília, macho, 6.XI1984, J. Dalmacio col. (MZSP); Mato Grosso: Chapada dos Guimarães, macho, 20.IX.1988 (MNRJ); Rio Verde, 400m, 3 machos, 2 fêmeas, XII.1962 (MNRJ); Sinop, 350m, 5 machos, X.1974, Alvarenga \& Roppa col. (MNRJ); Vianopólis, 2 machos, I.1970 S. A. Fragoso col. (MNRJ); Mato Grosso do Sul: Salobra, macho, 21.I.1955, C. A. C. Andrade col. (MZSP); Minas Gerais: Centralina, macho, XI.1947, A. Maller col. (MZSP).

\section{Coccoderus sexguttatus Waterhouse, 1880, revalidada} (Figs. 9, 27, 89, 91, 92, 94)

Coccoderus sexguttatus Waterhouse, 1880: 292; Lameere, 1883: 14; Martins \& Monné, 1980: 337, 338 (syn.); Monné, 1994: 10 (cat., in syn.).

Macho. Colorido geral alaranjado. Élitros transparentes, amarelados e com três pares de manchas ebúrneas ovais; distância entre as manchas cerca da metade do comprimento de uma mancha. Acima e abaixo das manchas medianas e posteriores com manchas castanho-escuras.

Cabeça com pontos finos e densos e pubescência esparsa e dourada. Olhos sem dimorfismo sexual; lobos oculares superiores com nove fileiras de omatídios; lobos inferiores não alcançam a face ventral da cabeça. Mandíbulas sem dimorfismo sexual e com um dente mediano aguçado no bordo interno. Genas triangulares, com ápices arredondados e cerca de um terço do diâmetro do lobo ocular inferior. Palpos labiais e maxilares desenvolvidos, ambos com artículos cilíndrico- 

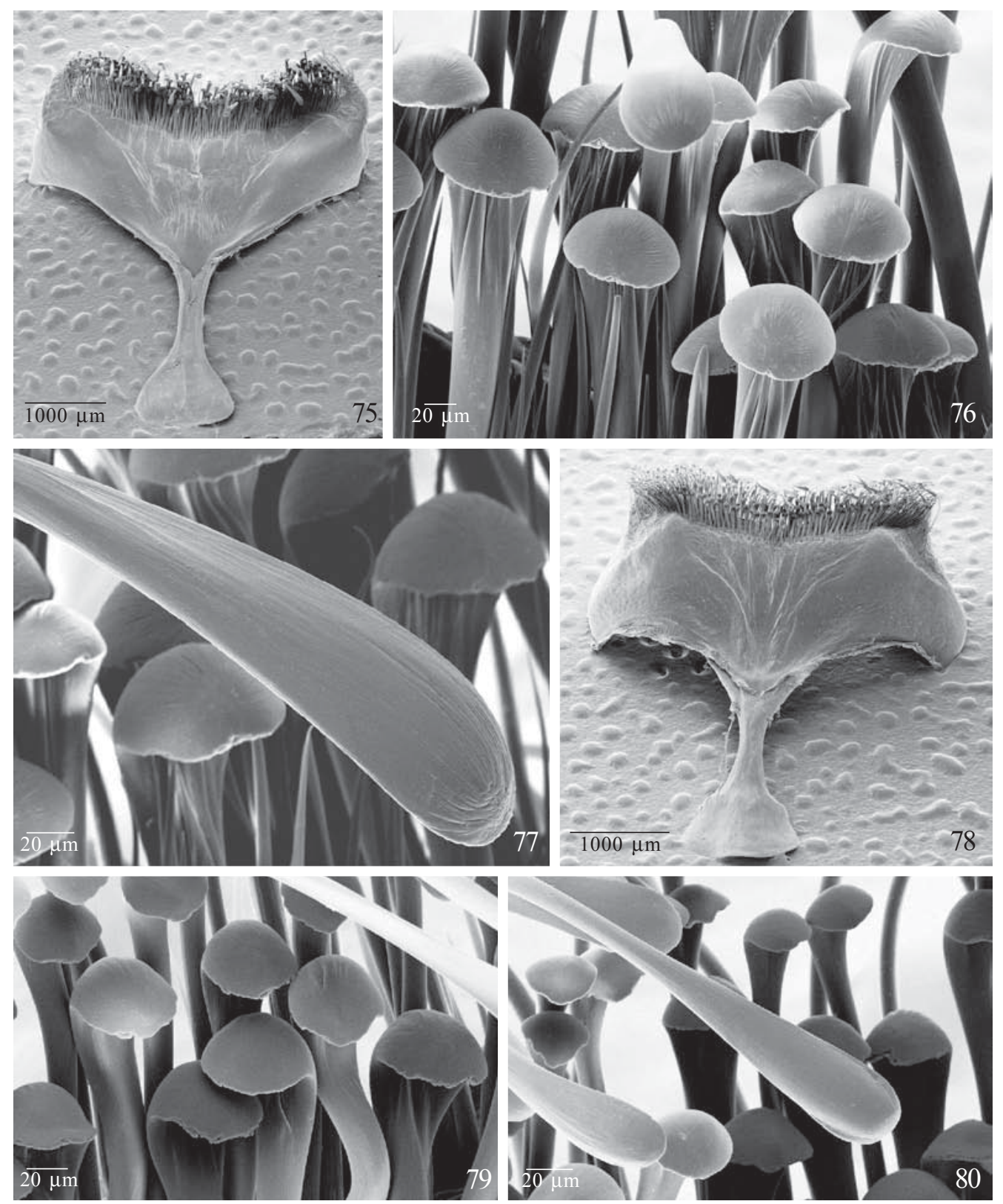

Figs. 75-80. Esternito VIII, fêmea. Coccoderus longespinicornis: 75, aspecto geral (25x), 76, detalhe dos pêlos conchoidais (500x), 77, detalhe dos pêlos aciculares e conchoidais (800x). Coccoderus sicki: 78, aspecto geral (30x), 79, detalhe dos pêlos conchoidais (800x), 80, detalhe dos pêlos espatulados e conchoidais $(800 \mathrm{x})$.

alongados; artículo apical dos labiais com comprimento subigual ao anterior; segundo artículo dos maxilares pouco mais longo que o terceiro e subigual ao apical. Antenas ultrapassam os ápices elitrais no antenômero VII; pilosidade esparsa e dourada. Sistema porífero no quarto apical da margem lateral externa dos antenômeros III-VII, pouco evidente nos VIII-XII. Escapo com pontos finos e esparsos; antenômero III (Fig. 9) cerca do dobro do escapo e sem projeção no ápice externo; IV-X com comprimentos subiguais; XI e XII com cerca de 2/3 do X; XII estreitado e curvado no ápice.

Protórax subglabro e com superfície rugoso-pontuada. Pronoto com pontos densos, rasos e irregulares; margem anterior truncada. Prosterno intumescido. Processo prosternal anguloso e sem tubérculo. Processo mesosternal convexo. Pernas com pontos finos e esparsos. Fêmures ligeiramente fusiformes. Esternito V (Fig. 27) com a margem apical truncada.

Fêmea. Palpos labiais e maxilares com artículos engrossados e mais curtos que nos machos; artículos apicais expandidos para o ápice. Antenas alcançam o terço apical dos élitros; sistema porífero no terço apical do antenômero III e em toda margem lateral externa dos IV-XII; antenômeros III-XII com ápice externo apenas anguloso; III cerca do dobro do comprimento do IV; IV-XI subiguais; XII um terço mais longo que o XI. 

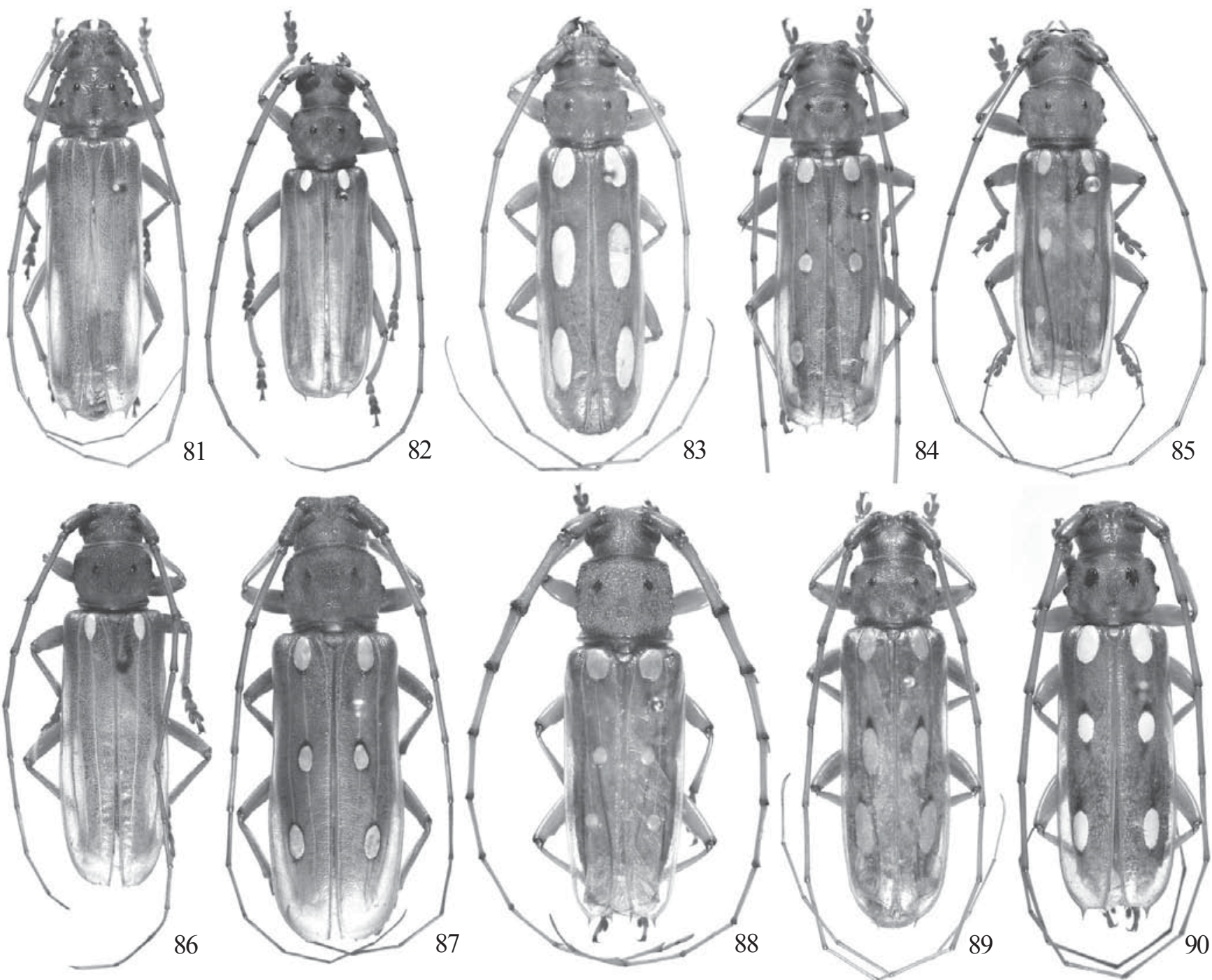

Figs. 81-85. 81, Coccoderus novempunctatus, macho, comprimento 27,5 mm; 82, C. bisignatus, macho, comprimento $39,0 \mathrm{~mm}$; 83 , C. sexmaculatus, macho, comprimento $24,1 \mathrm{~mm} ; 84$, C. amazonicus, macho, comprimento $29,5 \mathrm{~mm}$; 85 , C. guianensis, parátipo macho, comprimento $34,2 \mathrm{~mm} ; 86$, C. biguttatus, parátipo macho, comprimento $24,2 \mathrm{~mm} ; 87$, C. speciosus, macho, comprimento 32,5 mm; 88 , C. longespinicornis, macho, comprimento $25,3 \mathrm{~mm} ; 89$, C. sexguttatus, macho, comprimento $32,3 \mathrm{~mm}$; 90 , C. sicki, macho, comprimento 27,7 $\mathrm{mm}$.

Dimensões em mm, respectivamente, macho/fêmea. Comprimento total, 32,3/29,5-33,2; comprimento do protórax, 5,6/4,5-5,6; maior largura do protórax, 7,4/5,8-7,3; comprimento do élitro, 23,6/22,1-25,1; largura umeral, 8,3/6,8-9,1.

Material-tipo. Holótipo fêmea do Equador, [Morona-Santiago] Chiguinda (BMNH), examinado por meio de diapositivo feito por J. S. Moure (DZUP).

Discussão. O exame dos diapositivos dos holótipos de $C$. sexguttatus e C. amazonicus, do material examinado e da análise cladística, permitiu constatar que $C$. sexguttatus é uma espécie válida. C. sexguttatus é grupo-irmão de C. sicki (Fig. 91) por apresentarem: prosterno intumescido $\left(15_{2}\right)$; fêmures ligeiramente fusiformes (24 $)$; esternito $\mathrm{V}$ com margem apical truncada $\left(27_{2}\right)$. C. sexguttatus difere de $C$. sicki por apresentar o antenômero III inerme $\left(8_{0}\right)$ e mais longo que o IV; antenas, nas fêmeas, alcançam o terço apical dos élitros; margem anterior do pronoto truncada; élitros com distância entre as manchas ebúrneas com cerca da metade do comprimento de uma mancha $\left(20_{4}\right)$. Em C. sicki, o antenômero III é mais curto que o IV $\left(7_{1}\right) \mathrm{e}$ tem projeção espiniforme maior que a largura do antenômero; as antenas, nas fêmeas, ultrapassam os ápices elitrais $\left(9_{1}\right)$; a margem anterior do pronoto é arredondada (13 $)$; e os élitros apresentam distância entre as manchas ebúrneas cerca de duas vezes o comprimento de uma mancha.

Distribuição geográfica (Fig. 94). VENEZUELA, COLÔMBIA, EQUADOR, PERU. Provavelmente relacionada às regiões de matas orientais das encostas dos Andes.

Material examinado. VENEZUELA, Valencia: Puerto Cabello (Borburata), macho, VII.1940, Lichy col. (MNRJ). COLÔMBIA, Valle del Cauca: Cali, macho, 2 fêmeas, 1970 (MNRJ); Departamento Santander: $700-1300 \mathrm{~m}$, fêmea (7.29.35) (in trunk of Inga sp.) (MZSP); Antioquia: Valle Medelin, macho, IX.1949 (MZSP). PERU, Pasco: Oxapampa, 1600 m, fêmea, 1940, Weyrauch col. (MNRJ). 


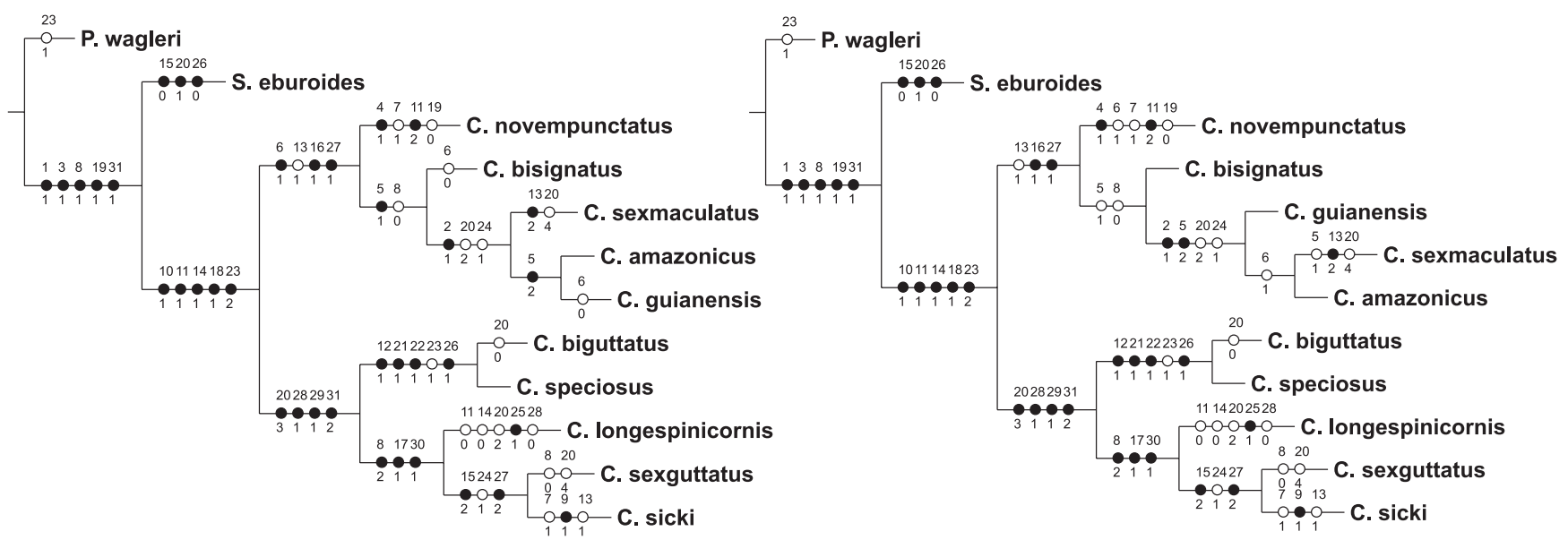

Figs. 91-92. Os dois cladogramas obtidos igualmente parcimoniosos $(\mathrm{L}=58, \mathrm{IC}=0,74, \mathrm{IR}=0,72)$, mostrando as relações de parentesco em Coccoderus e a distribuição dos caracteres. Círculos pretos= sinapomorfias; círculos brancos=homoplasias e/ou reversões.

Coccoderus sicki Lane, 1949

(Figs. 10, 18, 26, 33, 38, 43, 48, 54, 78-80, 90-92, 94)

Coccoderus sicki Lane, 1949: 36, pl. 1, fig. 2; Martins \& Monné, 1980: 338; Monné, 1994: 11 (cat.).

Macho. Colorido geral castanho-alaranjado. Élitros alaranjados na metade basal e transparentes e amarelados na metade apical; com três pares de manchas ebúrneas, distância entre as manchas cerca de duas vezes o comprimento de uma mancha.

Cabeça com pontos finos, rasos e esparsos, adensados nos tubérculos anteníferos; pêlos esparsos e alaranjados apenas na fronte. Olhos sem dimorfismo sexual; lobos oculares superiores com nove fileiras de omatídios; lobos inferiores não alcançam a face ventral da cabeça. Mandíbulas sem dimorfismo sexual e com um dente mediano no bordo interno. Genas triangulares com ápices arredondados, cerca de $1 / 4$ do diâmetro do lobo ocular inferior. Palpos labiais e maxilares com artículos moderadamente desenvolvidos, cilíndricos; artículos apicais atenuados na base e no ápice; artículo apical dos labiais com comprimento subigual ao anterior; o segundo dos maxilares mais longo que o apical. Antenas subglabras, com pontos finos e esparsos, ultrapassam os ápices elitrais no antenômero VII. Sistema porífero no terço apical do III e ao longo da margem lateral externa dos antenômeros IV-XII; antenômero III (Fig. 10) cerca de um terço mais curto que o IV e com projeção apical externa tão longa quanto a largura do antenômero; IV-X com comprimentos subiguais; XI-XII cerca de 1/4 mais curtos que o X e subiguais; XII estreitado e curvado no ápice.

Protórax subglabro, com pontos moderadamente grossos, rasos e densos. Pronoto com a margem anterior arredondada. Prosterno (Fig. 18) intumescido. Processo prosternal anguloso e sem tubérculo. Processo mesosternal convexo. Pernas com pontos e pêlos esparsos. Fêmures (Fig. 26) ligeiramente fusiformes. Esternito V com a margem apical truncada.

Terminália: esternito VIII (Fig. 33) transverso, margem apical sinuosa, com dois lobos; apófise esternal cerca da metade do comprimento do esternito. Arco ventral (Fig. 38) em forquilha, apófise subigual ao comprimento dos braços; ápice da apófise curvo. Arco dorsal reduzido, membranoso e pigmentado nas regiões laterais. Tégmen (Fig. 43) com região distal estreitada e quase inteiramente dividida em parâmeros cilíndricos, com ápices arredondados e com pêlos curtos; peça anelar arredondada e sem projeção apical. Lobo médio (Fig. 48): lobo ventral mais longo que o dorsal; o ventral atenuado para o ápice arredondado e o dorsal truncado no ápice; apófises basais ligeiramente mais longas que a porção apical. Saco interno com duas peças esclerotizadas em forma de gancho.

Fêmea. Palpos labiais e maxilares com artículos engrossados e mais curtos que nos machos; artículos apicais expandidos para o ápice. Antenas ultrapassam o ápice dos élitros no antenômero XI; III-IV com projeção aguçada no ápice externo e mais desenvolvida no III; III um terço mais longo que o IV; IV-XII gradualmente decrescentes; XII com ápice arredondado e reto. Esternito VIII (Figs. 78-80) com apófise expandida no ápice, com cerca de quatro vezes a largura da região mediana e ápice arredondado; margem apical ligeiramente sinuosa; pêlos aciculares mais curtos que os conchoidais; pêlos conchoidais e espatulados com ranhuras pouco evidentes na região dorsal. Ovipositor (Fig. 54) com lobos laterais divergentes e região basal arredondada aos lados; espermateca curva na região basal; glândula espermatecal mais curta que a espermateca.

Dimensões em mm, respectivamente, macho/fêmea. Comprimento total, 27,7-30,6; comprimento do protórax, 4,55,1 ; maior largura do protórax, 6,3-7,1; comprimento do élitro, 20,2-22,5; largura umeral, 7,0-8,2.

Material-tipo. Examinado o holótipo macho (MZSP) do Mato Grosso, Brasil.

\section{Discussão. Vide em C. sexguttatus.}

Distribuição geográfica (Fig. 94). BRASIL (Pará, Goiás, Rondônia, Distrito Federal, Mato Grosso). Possivelmente relacionada às matas de galeria do Cerrado. 


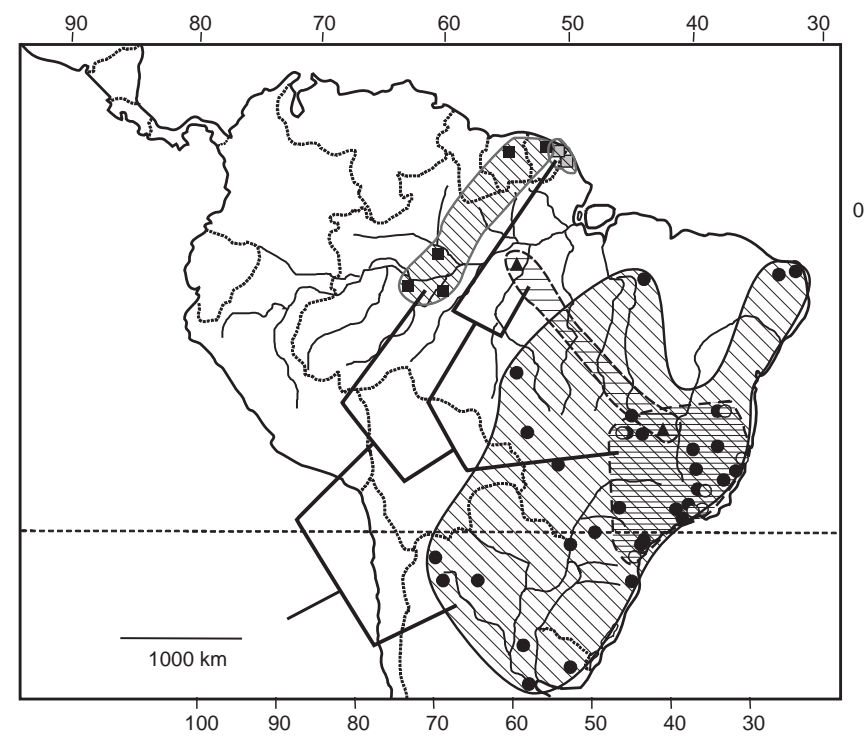

Fig. 93. Distribuição geográfica do clado de Coccoderus novempunctatus $+:$ C. novempunctatus $(\bullet), C$. bisignatus $(\square), C$. sexmaculatus $(\bigcirc)$, C. amazonicus $(\mathbf{\Lambda})$, C. guianensis $(\square)$.

Material examinado. BRASIL, Pará: Serra do Cachimbo, 2 fêmeas, X.1956, Travassos \& Adão col. (MNRJ); Goiás: Jataí, fêmea, X.1972, F. M. Oliveira col. (MNRJ); Parque Nacional Araguaia, 2 fêmeas, IX.1971, G. F. Santos col. (MNRJ). Rondônia: Vilhena, fêmea, macho, X.1974 (MNRJ); Distrito Federal: Planaltina, fêmea, II.XI.1977, V. O. Becker col. (CPAC); Mato Grosso: Rio Verde, 10 machos, XI.1962 (MNRJ); 2 fêmeas, XI.1960 (MNRJ); fêmea, X.1965, S. A. Fragoso col. (MNRJ); Barra do Bugres, fêmea, X.1984, B. Silva col. (MNRJ); Chavantina, fêmea (holótipo) acampamento da expedição RoncadorXingú, na margem direita do Rio das Mortes, XI.1946, Helmut Sick col. (MZSP).

\section{BIOGEOGRAFIA}

As espécies de Coccoderus apresentam ampla distribuição na América do Sul, não estando registradas ocorrências a oeste da cordilheira dos Andes, ao sul do paralelo $35^{\circ}$ e na região morfoclimática da Caatinga, no nordeste brasileiro (Figs. 93, 94).

Morrone $(2001,2004)$ dividiu a Região Neotropical em quatro sub-regiões biogeográficas: Caribenha, Amazônica, Chaquenha e Paranaense e estas em províncias. As espécies de Coccoderus estão assinaladas para todas as sub-regiões e, das dez espécies, sete ocorrem em simpatria na sub-região Chaquenha, na província do Cerrado.

As espécies do clado C. novempunctatus + (Fig. 93) distribuem-se ao norte do paralelo $35^{\circ}$ alcançando o norte do Brasil, Suriname e Guiana Francesa e ocorrem na sub-regiões Amazônica, Chaquenha e Paranaense. Coccoderus novempunctatus e C. sexmaculatus, ocorrem tanto na subregião Chaquenha como na Paranaense, sendo que $C$. sexmaculatus ocorre entre os paralelos $15^{\circ}$ e $25^{\circ}$ e $C$. novempunctatus apresenta ampla distribuição, ocorrendo ao leste da América do Sul: no norte, no Rio Grande do Norte e no Maranhão, não estando registrada para a Caatinga, e ao sul até a Argentina (Buenos Aires). Coccoderus bisignatus e $C$. guianensis ocorrem exclusivamente na sub-região Amazônica, e em simpatria na província da Guiana Úmida, sendo que $C$. bisignatus também ocorre nas províncias de Imerí e Madeira; ambas as espécies estão relacionadas à Floresta Amazônica (Hueck 1972). Coccoderus amazonicus é a única espécie, deste clado, que distribui-se nas sub-regiões Chaquenha e Amazônica.

As espécies do grupo C. biguttatus ++ (Fig. 94) ocorrem ao norte do Trópico de Capricórnio, limite que pode estar relacionado à formação de geadas nas matas subtropicais ao sul do Trópico (Hueck 1972), e uma espécie (C. sexguttatus) alcança o leste das encostas dos Andes. Distribuem-se em todas as quatro sub-regiões da região Neotropical (Morrone 2004) e não estão registradas para a Caatinga e Mata Atlântica (Rizzini et al. 1988). Das cinco espécies, quatro ocorrem em simpatria na província do Cerrado sendo que destas, $C$. biguttatus, $C$. sicki e $C$. speciosus encontram-se apenas no Cerrado e possivelmente estão relacionadas às formações florestais das matas de galeria (Ribeiro \& Walter 2001). Na sub-região Caribenha ocorrem duas espécies, C. sexguttatus e C. longespinicornis, em simpatria na província da Costa Venezuelana. Coccoderus sexguttatus ocorre na Venezuela, Colômbia, Equador e Peru, relacionada com as regiões das matas orientais das encostas dos Andes e distribui-se nas províncias de Cauca, Napo e Yungas, apresentando relação com a parte leste da sub-região Amazônica. Por outro lado, $C$. longespinicornis apresenta ampla distribuição, ocorrendo na Venezuela, Peru e Brasil e é a única espécie, neste grupo, que distribui-se nas subregiões Amazônica e Chaquenha.

Agradecimentos. A Miguel A. Monné (MNRJ), Sergio A. Vanin (USP) e Solange Napp (DZUP), pelas sugestões ao manuscrito. Aos

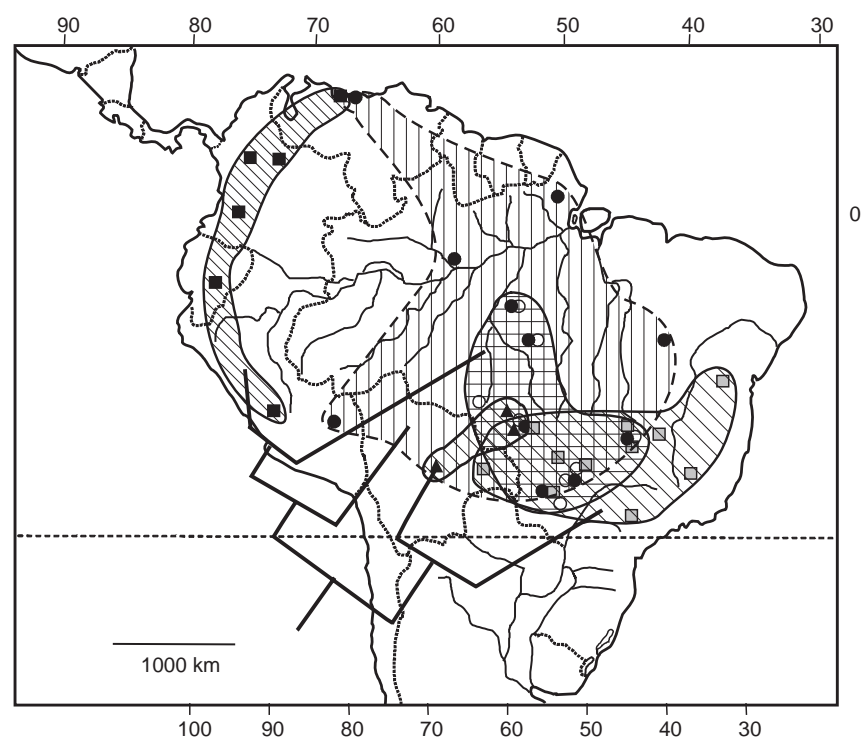

Fig. 94. Distribuição geográfica do clado de Coccoderus biguttatus + : $C$. biguttatus $(\boldsymbol{\triangle})$, C. speciosus $(\square)$, C. longespinicornis $(\bullet)$, C. sexguttatus (匹), C. sicki $(\bigcirc)$. 
curadores das instituições, pelo empréstimo do material estudado. Ao laboratório de microscopia eletrônica do Museu de Zoologia (MZSP). À FAPESP pela concessão da bolsa de estudos (Proc. 03/00511-3) e do auxílio à pesquisa (Proc. 03/03477-0).

\section{REFERÊNCIAS}

Amorim, D. S. 1982. Classificação por seqüenciação: uma proposta para a denominação de ramos retardados. Revista Brasileira de Zoologia 1: 1-9.

Bates, H. W. 1870. Contribution to an insect fauna of the Amazon Valley (Coleoptera: Cerambycidae). Transactions of the Entomological Society of London 1870: 243-335, 391-444.

Blanchard, C. E. 1847. In: Voyage dans l'Amérique méridionale (le Brésil, la République Orientale de l'Uruguay, la République Argentine, la Patagonie, la République du Chili, la République de Bolivia, la République du Pérou), exécute pendant les années $1826,1827,1828,1829,1830,1831,1832$ et 1833 par Alcide D'Orbigny. Insectes de l'Amérique méridionale, recueillis par Alcide D'Orbigny (Tribu des Longicornes). Paris, 6(2): 206-210, pls. 20-22.

Bondar, G. 1915. Insectos damninhos à Agricultura. Fascículo III. Pragas das laranjeiras e outras aurantiaceas. São Paulo, Aloizio \& Gallo, 48 p.

Buquet, J. B. L. 1840. Notice sur un genre nouveau de longicornes, de la tribu des cérambycins. Revue Zoologique 1840: 292-295.

Di Iorio, O. 1997. Plantas hospedadoras de Cerambycidae (Coleoptera) en el Espinal periestépico y en la provincia de Buenos Aires, Argentina. Revista de Biologia Tropical 44/45: 159-165.

Di Iorio, O. 1998. Torneutini (Coleoptera: Cerambycidae) of Argentina. Part 2. Biology of Coccoderus novempunctatus (Germar, 1824), Diploschema rotundicolle (Serville, 1834) and Praxithea derourei (Chabrillac, 1857). Giornale Italiano di Entomologia 9: 3-25.

Di Iorio, O. \& M. Zelich. 1997. Cerambycidae (Coleoptera) from Entre Ríos, Argentina. Part I. Hosts plants and distributions (with a revision of host plants for Uruguay). Giornale Italiano di Entomologia 8: 275-289.

Fragoso, S. A.; M. A. Monné \& C. A C. Seabra. 1987. Preliminary considerations on the higher classification of Cerambycinae (Coleoptera, Cerambycidae), with nomenclatural alterations. Revista Brasileira de Biologia 47: 189-202.

Fuchs, E. 1964. 6. Beitrag zur Kenntnis der neotropischen Cerambyciden. Koleopterologische Rundschau 42: 6-10.

Germar, E. F. 1839. In: Guérin-Ménéville, F. E. Note synonymique sur les cérambycins décrits par M. Germar, dans son Insectorum species novae aut minus cognitae, descriptionibus illustratae, Halae, 1824. Magazin de Zoologie 1839: 329-331.

Goloboff, P. A. 1993. NONA Version 2.0 (for windows). INSUE Fundación y Instituto Miguel Lillo, Miguel Lillo 205, 4000 S. M. de Tucumán, Argentina.

Gounelle, E. 1909. Liste des cérambycides de la région de Jatahy, Etat de Goyaz, Brésil. Annales de la Société Entomologique de France 77: 587-688.

Hueck, K. 1972. As florestas da América do Sul. São Paulo, Polígono, XXII+466 p.

Lane, F. 1939. Descrições de longicórnios neotrópicos (nota prévia). Boletím Biológico (n. s.) 4: 73-78.

Lane, F. 1949. Cerambicideos neotrópicos I. Sôbre algumas espécies de Torneutinae (Col., Cerambycidae). Papéis Avulsos do Departamento de Zoologia 9: 33-46.

Lane, F. \& U. R. Martins. 1965. Nova espécie de Coccoderus Buquet, 1840 (Col., Cerambycidae). Papéis Avulsos do Departamento de Zoologia 18: 17-20.

Marques, M. I. \& D. S. Napp. 1996. Revisão e transferência para Rhopalophorini (Coleoptera, Cerambycidae, Cerambycinae) dos gêneros Coremia Audinet-Serville, 1834 e Merocoremia Marques, 1994. Revista Brasileira de Entomologia 40: 379-423.

Martins, U. R. 1985. Novos táxons, sinonímias, notas e nova combinação em Cerambycidae (Coleoptera) neotropicais. Revista brasileira de Entomologia 29: 169-180.

Martins, U. R. \& M. A. Monné. 1980. Torneutini (Coleoptera, Cerambycidae): chave para os gêneros, chave para espécies de alguns gêneros, notas e descrições de novos taxa. Papéis Avulsos de Zoologia 33: 335-353.

Monné, M. A. 1994. Catalogue of the Cerambycidae (Coleoptera) of the Western Hemisphere. Part XI. Subfamily Cerambycinae: Tribes Torneutini, Trachyderini and Basipterini. São Paulo, Sociedade Brasileira de Entomologia, 157 p.

Monné, M. A. 2001. Catalogue of the Neotropical Cerambycidae (Coleoptera) with known host plant - Part II: Subfamily Cerambycinae, Tribes Graciliini to Trachyderini. Publicações Avulsas do Museu Nacional 90: 1-119.

Monné, M. L. \& D. S. Napp. (in press). Cladistic analysis of the tribe Torneutini (Coleoptera, Cerambycidae, Cerambycinae, Trachyderoinia). Zootaxa.

Morrone, J. J. 2001. Biogeografia de América Latina y el Caribe. Zaragoza, M \& T-Manuales \& Tesis SEA, vol. 3, 148 p.

Morrone, J. J. 2004. Panbiogeografia, componentes bióticos y zonas de transición. Revista Brasileira de Entomologia 48: 149162 .

Nixon, K. C. 1999. Winclada (beta) version 0.9.99m24. Ithaca Published by the author.

Nixon, K. C. \& J. M. Carpenter. 1993. On outgroups. Cladistics 9: 413-426.

Page, R. D. M. (2001). NDE (NEXUS data editor for windows). Version 0.5.0 NDE- home page (http://taxonomy.zoology.gla.ac.uk/ $\mathrm{rod} / \mathrm{NDE} / \mathrm{nde} \cdot \mathrm{html})$.

Rizzini, C. T.; A. F. Coimbra Filho \& A. Houaiss. 1988. Ecossistemas Brasileiros. Rio de Janeiro, Index, $200 \mathrm{p}$.

Ribeiro, J. F. \& B. M. T. Walter. 2001. As Matas de Galeria no contexto do bioma Cerrado, p. 29-45. In: Cerrado: caracterização e recuperação de matas de galeria. Planaltina, Embrapa Cerrados, 899 p.

Silva, A. G. D’Araujo \& D. G. Almeida. 1941. Entomologia Florestal. Contribuição ao estudo das coleobrocas. Publicações da Divisão de Defesa Sanitária Vegetal 16: 1-100.

Swofford, D. L. 2001. Phylogenetic Analysis Using Parsimony (PAUP), Version 4.0b10 for 32-bit Microsoft (beta test version). Sunderland, Sinauer Associates, Inc.

Tavakilian, G. L. \& M. L. Monné. 2002. Torneutini de Guyane: nouvelles espèces et notes complémentaires (Coleoptera, Cerambycidae). Coléoptères 8: 9-35.

Thomson, J. 1864. Systema cerambycidarum ou exposé de tous les genres compris dans la famille des cérambycides et familles limitrophes. Mémoires de la Société Royale des Sciences de Liège 19: 1-540.

Waterhouse, C. O. 1880. New South-American Coleoptera, chiefly from Ecuador. The Annals and Magazine of Natural History 5: $285-302$

White, A. 1853. Catalogue of the coleopterous insects in the collection of the British Museum. Longicornia 1. London, British Museum, 7: 1-174.

Zajciw, D. 1972. Contribuição para o estudo da fauna dos longicórneos do Parque Nacional do Itatiaia (Coleoptera, Cerambycidae). Brasil Florestal 3: $40-72$ 